\title{
Development of a Hydrologic and Water Allocation Model to Assess Water Availability in the Sabor River Basin (Portugal)
}

\author{
Regina Maria Bessa Santos ${ }^{1}$, Luís Filipe Sanches Fernandes ${ }^{1}$ (D), Rui Manuel Vitor Cortes ${ }^{1}$ (D) \\ and Fernando António Leal Pacheco ${ }^{2, *}$ (D) \\ 1 Centre for the Research and Technology of Agro-Environment and Biological Sciences, \\ University of Trás-os-Montes and Alto Douro, Ap. 1013, 5001-801 Vila Real, Portugal \\ 2 Chemistry Research Centre, University of Trás-os-Montes and Alto Douro, Ap. 1013, \\ 5001-801 Vila Real, Portugal \\ * Correspondence: fpacheco@utad.pt
}

Received: 1 May 2019; Accepted: 6 July 2019; Published: 8 July 2019

\begin{abstract}
The Sabor River basin is a large basin $\left(3170 \mathrm{~km}^{2}\right)$ located in the northeast of Portugal and used mostly for agroforestry. One problem this basin faces is a lack of water during the dry season, when there is a higher demand for water to irrigate crops. To solve this problem, the Portuguese government created a National Irrigation Program to finance new irrigation areas and improve existing ones. Consequently, it is necessary to evaluate the past and future water availability for agricultural and domestic consumption in the basin. This was done through the development of a hydrological and water allocation model. The Soil and Water Assessment Tool (SWAT) was used to model the hydrological processes that took place in the catchment between 1960 and 2008. The MIKE HYDRO Basin was used to simulate water allocation (irrigation and domestic consumption) in a historical view and under two scenarios. The historical view used the time period 1960-2008, and the two scenarios used the same time period but with an increase in the irrigated area. The first scenario simulated the irrigation of the total irrigable area that exists in the basin. The second scenario simulated a $29 \%$ increase in the olive grove area and a $24 \%$ decrease in the resident population, according to the projection for 2060 . The results show that, in the historical view, the average annual water demand deficit was 31\% for domestic consumption and 70\% for irrigation, which represent $1372 \times 10^{3} \mathrm{~m}^{3}$ and $94 \times 10^{6} \mathrm{~m}^{3}$ of water, respectively. In the two scenarios, the water demand deficit increased to $37 \%$ for domestic consumption and $77 \%$ for irrigation. In the first scenario, the average annual water demand deficit was $183 \times 10^{6} \mathrm{~m}^{3}$ of water for irrigation. In the second scenario, the average annual water demand deficit was $385 \times 10^{3} \mathrm{~m}^{3}$ of water for domestic consumption, and $106 \times 10^{6} \mathrm{~m}^{3}$ of water for irrigating the expanded olive grove area. These results demonstrate that Portuguese farmers can use our model as a decision support tool to determine how much water needs to be stored to meet the present and future water demand.
\end{abstract}

Keywords: SWAT; MIKE HYDRO Basin; irrigation demand; applied irrigation; irrigation deficit; domestic consumption; resident population

\section{Introduction}

Portugal is a country with an average annual rainfall of around $700 \mathrm{~mm}$. However, irregular distribution generates water scarcity problems from April to September, particularly in the south and (central and northern) interior of the country. As a result, the spring-summer crops do not have sufficient irrigation to ensure a satisfactory level of production. In this respect, irrigation is a 
fundamental component of agriculture, without which it is not possible to suitably develop the spring and summer crops.

To solve this problem, the Portuguese government created a National Irrigation Program. The program will make available 534 million euros to create 90,000 hectares of irrigation area with the aim of rehabilitating and modernizing the current irrigation system [1]. The Sabor River basin is included in the national irrigation program, and one of the main objectives of farmers is the expansion of its olive grove area.

The Sabor River basin is located in the Trás-os-Montes region, where the main economic activities are agriculture and livestock farms [2]. This region is dominated by farms that specialize in permanent crops $(57 \%)$, such as vineyards $(24 \%)$, fruit trees $(8 \%)$, olive groves $(9 \%)$, and combinations of them $(16 \%)$. The spatial distribution of these crops shows a concentration of viticulture in the Douro Demarcated Region, olive groves in the centre of the region, which is called "warm land", and a dispersion of farms that specialize in nut, chestnut, and almond trees [3]. According to the agricultural census [4-6], the total area of the olive groves in the Trás-os-Montes region increased by $135 \mathrm{~km}^{2}$ between 1989 and 2008. This crop is essentially a dryland crop, as only 7\% of the area is irrigated according to the agricultural census of 1999 [6].

The general aims of this study are: (i) to determine whether the quantity of water that was produced in the basin between 1960 and 2008 was sufficient to satisfy the requirements of the crops; and (ii) to determine how much water would be needed if the irrigation area was to be increased according to the proposal in the National Irrigation Program. To achieve these aims, we create two scenarios: one to determine how much water is required to irrigate the entire irrigable area that currently exists in the basin, and one based on the expansion of the olive grove area according to a projection for 2060. This study also included the evolution of the resident population between 1960 and 2008, and a demographic projection to 2060.

In order to study the feasibility of water demand, a hydrological and allocation analysis of the basin's response to agricultural practices and water consumption was carried out. This analysis included a study of the hydrological characteristics of the basin and the development of a hydrological and water allocation model for the basin area. With the advancement of modeling technology, several hydrological models have been developed, ranging from lumped conceptual to physically based distributed models [7]. Watershed models have become a crucial tool for analyzing a wide variety of hitches in water resources, including planning, development, and management. In this study, we propose the use of two separate software packages: Soil and Water Assessment Tool (SWAT) and MIKE HYDRO Basin. The SWAT model is a physical model that requires the introduction of a series of spatiotemporal data to predict the impact of human interventions (e.g., changes in agriculture practices and the addition of chemical fertilizers) on hydrological and chemical processes in river basins [8]. MIKE HYDRO Basin was developed by the Danish Hydraulic Institute [9] and is used as a decision support tool for integrating water resources management and planning in a river basin. This software provides comprehensive hydrological modeling for basin-scale solutions and accommodates a basin-wide representation of water availability and water demand [10].

In this context, the objective of this study is to evaluate the present and future agricultural sustainability of the Sabor River basin through the development of a hydrological and water allocation model (an integration of SWAT and MIKE HYDRO Basin). The specific aims of this study are: (i) to determine whether the quantity of water produced in the basin between 1960 and 2008 was sufficient to satisfy the requirements of the crops and the domestic consumption; and (ii) to determine the quantity of water that will be necessary: (a) to irrigate the total irrigable area that exists in the basin (the first scenario); and (b) with a $24 \%$ decrease in the resident population and a $29 \%$ increase in the olive grove area for 2060 (the second scenario). 


\section{Materials and Methods}

\subsection{Study Area}

The present work was carried out in an agro-forested basin in the northeast of Portugal. The Sabor River basin is a tributary of the Douro River (Figure 1). The main watercourse, with its headwaters located in Spain, is $212.6 \mathrm{~km}$ long, and the catchment has an area of approximately $3834.5 \mathrm{~km}^{2}$ (3170.7 $\mathrm{km}^{2}$ for the Portuguese part). The average annual precipitation and temperature in the region for the period 1957-2008 were $730 \mathrm{~mm} \cdot$ year $^{-1}$ and $12.5^{\circ} \mathrm{C}$, respectively [11]. The weather is typical Mediterranean, characterized by high temperatures and low air humidity in summer [12] and high annual and interannual differences in rainfall quantity and intensity in the autumn and winter months [13]. In the Sabor River basin, the elevation ranges between 88 and $1464 \mathrm{~m}$ (Figure 1a). Slopes of less than $15 \%$ occupy $58 \%$ of the basin according to the Directorate-General of Territory [14]. The soils are dominated by Lithosols (87\% of the catchment area), but Cambisols (7.4\%), Alisols (3\%), Anthrosols (1.4\%), and Fluvisols (0.7\%) are also present [15]. According to the Corine Land Cover 1990 data published by the European Environmental Agency [16], agricultural area occupies 59\%, semi-natural area occupies 31\%, and forested area occupies $9 \%$ of the total basin area. The remaining $1 \%$ is covered by artificial areas and water bodies. According to Statistics Portugal, the irrigation of crop land consumes, on average, $6733 \mathrm{~m}^{3}$ of water per hectare per year [17], and, in the Trás-os-Montes region, $70 \%$ of this water is groundwater [18].
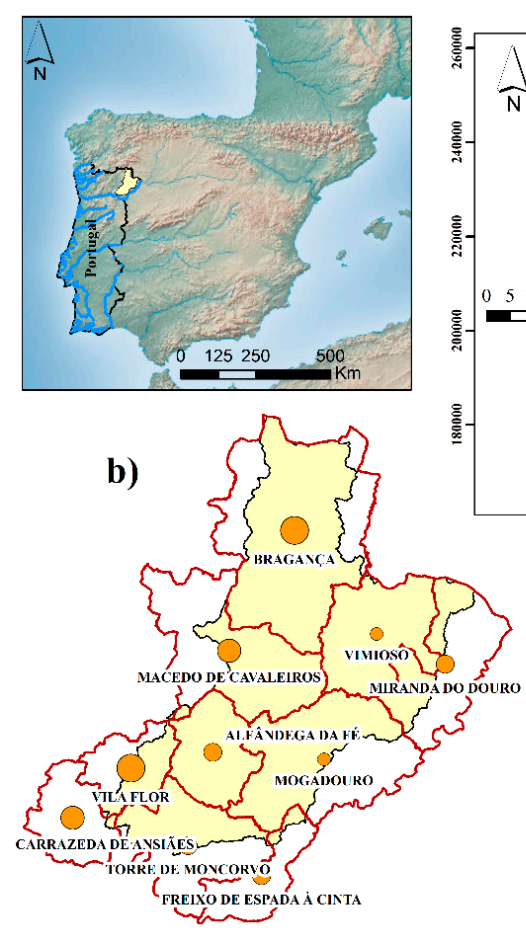

Population density (census 2011) Inhabitants.km ${ }^{-2}$

$10-15$

$16-20$

$26-30$

$\square$ Administrative limits
$\square$ Sabor River Basin

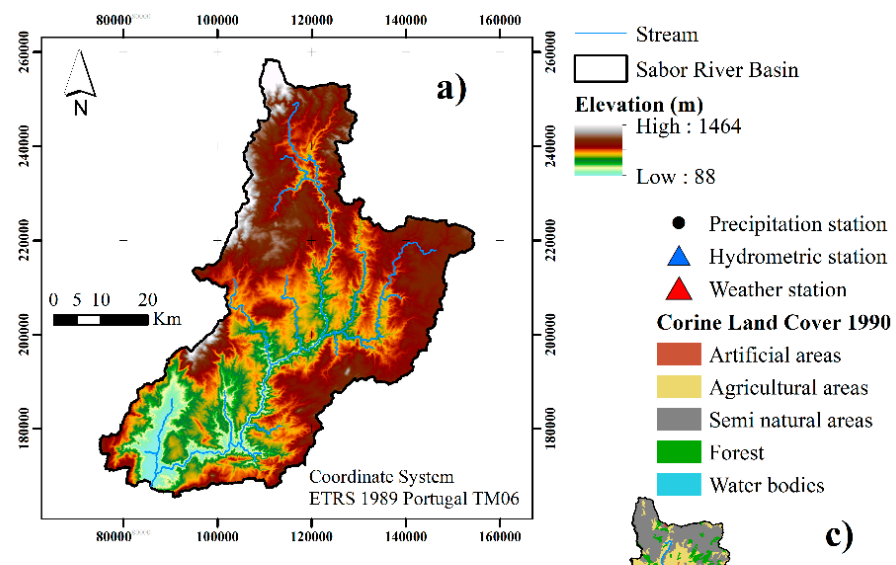

c)

Figure 1. Geographical location of the Sabor River basin. (a) Topography and drainage network, (b) population density per municipality according to the 2011 census, and (c) hydro-meteorological data and the Corine land cover 1990.

According to the 2011 census, the population density in the municipalities of the Sabor River basin was on average 20 inhabitants $\cdot \mathrm{km}^{-2}$ (Table 1) [19]. The highest population density (greater than 21 inhabitants $\cdot \mathrm{km}^{-2}$ ) was located in West of the basin, in the municipalities Bragança, Macedo de Cavaleiros, Vila Flor, and Carrazeda de Ansiães (Figure 1b). However, from 1960 to 2011, the population density decreased to 14 inhabitants $\cdot \mathrm{km}^{-2}$. In this period, the resident population was 176,947 and 103,336 inhabitants, respectively (Table 1). In this period, the average of the decrease was $42 \%$ with values that ranged between 63\% in Vimioso and 6\% in Bragança. In terms of domestic water 
consumption, the average of all municipalities was $50 \mathrm{~L} \cdot \mathrm{day}^{-1}$ with values that ranged between

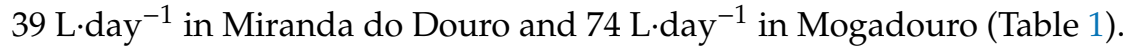

Table 1. The resident population in 1960 and 2011 and the variation in population per municipality according to Statistics Portugal [19]. The population density in 1960 and 2011 and the domestic water consumption per capita between 1995 and 2009 per municipality in the Sabor River basin. The domestic water consumption per capita is available at PORDATA [20]. The legend is: VP 1960-2011 (\%), the variation in population between 1960 and 2011 (\%); DWCPC 1995-2009 (L·day ${ }^{-1}$ ), the domestic water consumption per capita between 1995 and $2009\left(\mathrm{~L} \cdot d a y^{-1}\right)$.

\begin{tabular}{|c|c|c|c|c|c|c|}
\hline Municipality & $\begin{array}{l}\text { Resident } \\
\text { Population } \\
\text { in } 1960\end{array}$ & $\begin{array}{l}\text { Resident } \\
\text { Population } \\
\text { in } 2011\end{array}$ & $\begin{array}{c}\text { VP } \\
1960-2011 \\
(\%)\end{array}$ & $\begin{array}{c}\text { Population } \\
\text { Density in } 1960 \\
\text { (inhabitants } \cdot \mathrm{km}^{-2} \text { ) }\end{array}$ & $\begin{array}{c}\text { Population } \\
\text { Density in } 2011 \\
\text { (inhabitants } \cdot \mathbf{k m}^{-2} \text { ) }\end{array}$ & $\begin{array}{c}\text { DWCPC } \\
\text { 1995-2009 } \\
\left(\text { L }^{\text {day }}{ }^{-1}\right)\end{array}$ \\
\hline Alfândega da Fé & 9659 & 5104 & -47 & 30 & 16 & 43 \\
\hline Bragança & 37,556 & 35,341 & -6 & 32 & 30 & 44 \\
\hline Carrazeda de Ansiães & 14,326 & 6373 & -56 & 51 & 23 & 45 \\
\hline Freixo de Espada à Cinta & 7252 & 3780 & -48 & 30 & 15 & 55 \\
\hline Macedo de Cavaleiros & 26,219 & 15,776 & -40 & 38 & 23 & 47 \\
\hline Miranda do Douro & 18,952 & 7482 & -61 & 39 & 15 & 39 \\
\hline Mogadouro & 19,626 & 9542 & -51 & 26 & 13 & 74 \\
\hline Torre de Moncorvo & 18,765 & 8572 & -54 & 35 & 16 & 54 \\
\hline Vila Flor & 11,829 & 6697 & -43 & 45 & 25 & 43 \\
\hline Vimioso & 12,763 & 4669 & -63 & 27 & 10 & 55 \\
\hline Total & 176,947 & 103,336 & -42 & 34 & 20 & 50 \\
\hline
\end{tabular}

\subsection{Identification of Irrigable Crops}

The Land Use and Land Cover (LULC) of Continental Portugal for 2007 (COS2007) was used to calculate the irrigable area in the Sabor River Basin. These land use data were selected because they have a scale of 1:25,000 and a minimum cartographic unit of 1 hectare [21]. The COS2007 is a European initiative, included in the Coordination of Information on the Environment (CORINE) program, in which one of the main components is cartographic information on land use and cover [22]. The nomenclature of COS2007 is hierarchical, with five levels and 193 LULC classes at the most detailed level. We identified seven irrigable crops: maize, potato, olive groves, fruit trees, horticulture, vineyards, and forages (Table 2). The crops attributed to each class (level five) of COS2007 and the respective areas can be found in supplementary material, worksheet 1 . The class Temporary irrigated land associated with olive groves, fruit trees, and agroforestry systems was classified as 50\% maize and $50 \%$ potato. The class Agriculture with natural vegetation and semi-natural areas was also classified as $50 \%$ maize and $50 \%$ potato, but only $25 \%$ of the area of this class is considered to be irrigable area according to the description of [21]. The class Complex cultivation patterns was classified as $100 \%$ horticulture, but only $75 \%$ of the area of this class is considered to be irrigable area according to the description of [21]. The classes Olives groves and Olives groves with orchards or vineyards were classified as $100 \%$ olives, and the Orchard classes, such as almond, chestnut, citrus, and fresh fruit, were classified as $100 \%$ orchards. The classes Vineyards and Vineyards with olive groves or orchards were classified as $100 \%$ vineyards and the class Permanent pastures was classified as $100 \%$ forages. This classification shows that, in the study area, the dominant form of agriculture is olive groves, with $322 \mathrm{~km}^{2}$ distributed over the centre and southeast of the basin (Table 2). Fruit trees are the second most dominant form of agriculture, with $130 \mathrm{~km}^{2}$ of area located essentially in the north of the basin.

However, according to the agricultural census of 1999 [3], only a small percentage of the irrigable area is, in fact, irrigated. The irrigable area is defined as the maximum crop area that is available for irrigation, and the irrigated area is defined as the area that is irrigated at least once a year. On this basis, the crops with a major percentage of the irrigated area were maize and potato with $90 \%$ and $80 \%$, respectively, compared to forages, which had only $5 \%$ of the irrigated area (Table 2). 
Table 2. The crops that were identified in the Sabor River Basin and their irrigable area and irrigated area according to agricultural census of 1999.

\begin{tabular}{cccc}
\hline Crop & Irrigable Area $\left.\mathbf{( k m}^{\mathbf{2}}\right)$ & Irrigated Area $\mathbf{( \% )}$ & Irrigated Area $\mathbf{( k m}^{\mathbf{2}} \mathbf{)}$ \\
\hline Maize & 28.5 & 90 & 25.7 \\
Potato & 28.5 & 80 & 22.8 \\
Vineyards & 43.4 & 7 & 3.04 \\
Olive groves & 321.8 & 7 & 22.5 \\
Fruit trees & 130.8 & 70 & 91.5 \\
Forages & 1.8 & 5 & 0.09 \\
Horticulture & 31.9 & 50 & 15.9 \\
Total & $\mathbf{5 8 6 . 7}$ & - & $\mathbf{1 8 1 . 5}$ \\
\hline
\end{tabular}

\subsection{Conceptual Framework}

A conceptual framework was developed to model the hydrology and water allocation in the Sabor River basin (Figure 2). For that, we used a modelling method that integrates the software packages SWAT and MIKE HYDRO Basin. In SWAT, a detailed database of the catchment was developed for hydrological analysis and modelling. The database was composed of the following data: digital elevation model, land use and land cover, soil characteristics, and hydro-meteorological data. A hydrological model was constructed using all these data. Then, this model was calibrated using data from the period 1960-1999 in the SWAT-CUP (Calibration and Uncertainty Procedures) software and validated using data from the period 2000-2008. After that, the hydrological model was used to simulate the hydrologic processes in the Sabor River basin during the period 1960-2008 and some output data were input into MIKE HYDRO Basin. The output data were: drainage network, basin and sub-basin delimitation, surface runoff, aquifer recharge, rainfall, and potential evapotranspiration at sub-basin scale data. Then, the data on the water that was used for domestic consumption and irrigation, at the sub-basin scale, were also input into MIKE HYDRO Basin.

In MIKE HYDRO Basin, a first phase simulated the water that was used for domestic consumption and irrigation between 1960 and 2008. This period was called the historical view. In a second phase, two scenarios were created: the first was used to simulate the water that was used for domestic consumption between 1960 and 2008 assuming, with respect to irrigation, that the entire irrigable area identified in COS2007 was irrigated [21]. The second scenario was used to simulate the expansion of the olive grove area and the decrease in the resident population according to the projection for 2060. The simulation for the two scenarios was performed with surface runoff, aquifer recharge, precipitation, and reference evapotranspiration data for the period 1960-2008. All simulations were performed on a daily time step between 1960 and 2008 in both SWAT and MIKE HYDRO Basin.

The historical view and the two scenarios were analyzed in order to evaluate the impacts of water management, agricultural practices, and the demographic trend on water allocation in the Sabor River basin.

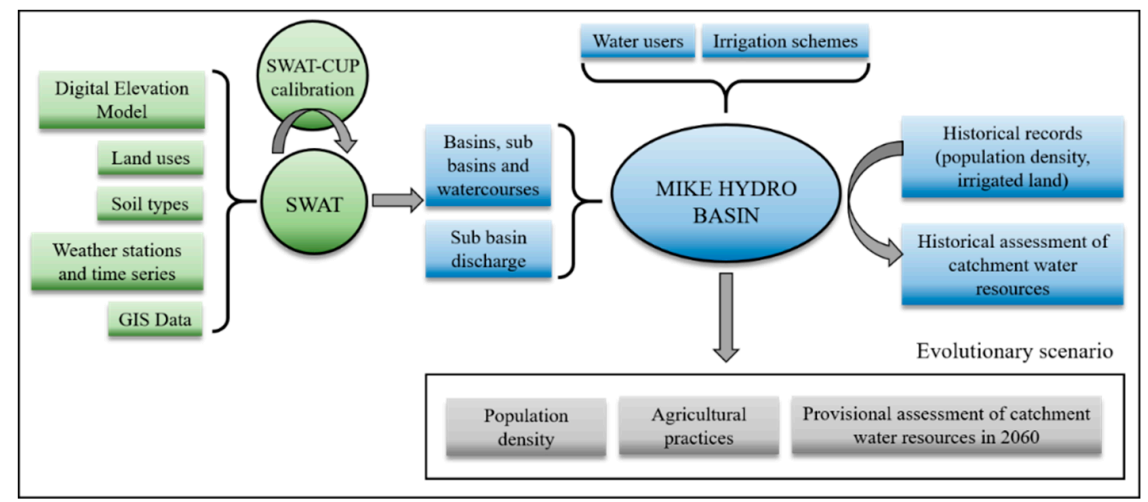

Figure 2. The process and concept for the Soil and Water Assessment Tool (SWAT) and MIKE HYDRO Basin models. 


\subsection{SWAT Hydrological Model and Calibration}

The SWAT model has been applied all over the world, to watersheds of different sizes, and to assess the effects of climate and land use changes on water balance, water quantity, nutrient exportation, and soil erosion [23]. This software is based on a mathematical model developed by the United States Department of Agriculture (USDA) [23,24]. SWAT runs in the Geographic Information System (GIS) software ArcMap (www.esri.com) developed by the Environmental Systems Research Institute (ESRI; Redlands, NY, United States) and widely applied to environmental studies [25-34]. In this study, the 2012 version of SWAT was used to model the hydrologic processes in the Sabor River basin. Into this software, we inserted digital elevation model, land-cover map, soil-type map, and meteorological data. The sources and scale of the data are summarized in Table 3.

Table 3. The data input into SWAT and MIKE HYDRO Basin.

\begin{tabular}{|c|c|c|}
\hline Data Type & Description & Source \\
\hline Topography & Digital Elevation Model (10 m) & $\begin{array}{l}\text { Directorate-General of Territory } \\
\text { http://www.dgterritorio.pt/ }\end{array}$ \\
\hline Land use & $\begin{array}{l}\text { Corine Land Cover 1990, } 2000 \text { and } 2006 \\
\qquad(1: 100,000)\end{array}$ & $\begin{array}{l}\text { European Environment Agency } \\
\text { http://www.eea.europa.eu/ }\end{array}$ \\
\hline Soil type & $\begin{array}{c}\text { Soil map of Trás-os-Montes and Alto } \\
\text { Douro }(1: 100,000)\end{array}$ & $\begin{array}{c}\text { Directorate-General of Territory } \\
\text { http://scrif.igeo.pt/ }\end{array}$ \\
\hline Meteorology & $\begin{array}{l}\text { Daily precipitation, maximum and } \\
\text { minimum temperatures, solar radiation, } \\
\text { relative humidity, and wind speed }\end{array}$ & $\begin{array}{l}\text { National System of Water } \\
\text { Resources Information } \\
\text { https://snirh.apambiente.pt/ }\end{array}$ \\
\hline Hydrography & $\begin{array}{l}\text { Daily streamflow between } 1957 \\
\text { and } 2008\end{array}$ & $\begin{array}{l}\text { National System of Water } \\
\text { Resources Information } \\
\text { https://snirh.apambiente.pt/ }\end{array}$ \\
\hline Resident population & $\begin{array}{l}\text { Number of inhabitants per year and per } \\
\text { municipality between } 1960 \text { and } 2008\end{array}$ & $\begin{array}{l}\text { Statistics Portugal } \\
\text { https://www.ine.pt/ }\end{array}$ \\
\hline Water consumption & $\begin{array}{l}\text { Domestic water consumption per } \\
\text { municipality }\left({\left.\mathrm{L} \cdot \text { day }^{-1} \cdot \text { inabitant }^{-1}\right) \text { for }}^{\text {the years } 1995,2001,2006,2008 \text { and }^{2} 2009}\right.\end{array}$ & $\begin{array}{l}\text { Data base of Portugal } \\
\text { https://www.pordata.pt/ }\end{array}$ \\
\hline COS2007 & Land use and land cover of 2007 & $\begin{array}{l}\text { Directorate-General of Territory } \\
\text { http://www.dgterritorio.pt/ }\end{array}$ \\
\hline COS2015 & Land use and land cover of 2015 & $\begin{array}{l}\text { Directorate-General of Territory } \\
\text { http://www.dgterritorio.pt/ }\end{array}$ \\
\hline FAO 56 & $\begin{array}{l}\text { FAO-56 Dual Crop Coefficient method. } \\
\text { Tables of chapters } 6,7 \text { and } 8\end{array}$ & $\begin{array}{c}\text { Food and Agriculture } \\
\text { Organization of the United } \\
\text { Nations } \\
\text { http://www.fao.org/home/en/ }\end{array}$ \\
\hline $\begin{array}{l}\text { Projection of the resident } \\
\text { population }\end{array}$ & $\begin{array}{l}\text { Projection of number of inhabitants } \\
\text { for } 2060\end{array}$ & $\begin{array}{l}\text { Statistics of Portugal } \\
\text { https://www.ine.pt/ }\end{array}$ \\
\hline $\begin{array}{l}\text { Projection of the irrigable } \\
\text { area of olive groves }\end{array}$ & $\begin{array}{l}\text { Projection of the irrigable area of olive } \\
\text { groves for } 2060 \text { based on increased } \\
\text { between COS2007 and COS2015 }\end{array}$ & $\begin{array}{l}\text { Directorate-General of Territory } \\
\text { http://www.dgterritorio.pt/ }\end{array}$ \\
\hline
\end{tabular}

The Trás-os-Montes and Alto Douro digital elevation models, which are available from the Directorate-General of Territory (http://www.dgterritorio.pt/), were used to delimit 37 sub-basins and define the drainage network. The Corine Land Cover (CLC) of 1990, 2000, and 2006, which are available from the European Environment Agency [16], were used as a land cover map. The CLC 1990, 2000, and 2006 data were used to model the land cover between 1960 and 1999, between 2000 and 2005, and between 2006 and 2009, respectively. The Trás-os-Montes and Alto Douro soil type data, which are available from the Directorate-General of the Territory [14], were used as a soil type 
map. The precipitation data from 11 meteorological stations and the meteorological data from the Folgares station (06N/01C) (Figure 1c), which are available from the National System of Water Resources Information [35], were inserted into the SWAT model. The Thiessen polygon method was selected to interpolate the precipitation data from the basin. The meteorological data from Folgares station was used in the Penman-Monteith equation. More details on the input data can be found in Santos et al. [36]. With all these data, the SWAT hydrological model of the Sabor River basin was executed for the period 1960-1999. Then, the hydrological model was calibrated and validated with streamflow data that were collected at the Quinta das Laranjeiras hydrometric stations between 1960 and 1999 and between 2000 and 2008, respectively. The calibrated model's parameters are presented in Santos et al. [36]. A complete description of the SWAT model and its underlying theory can be found in [37].

The model's calibration was performed using the SWAT-CUP 2012 software on a daily time step [24,37]. The model's performance (defined as the goodness-of-fit between the observed and the calibrated streamflow) was evaluated using the coefficient of determination $\left(R^{2}\right)$, the Nash-Sutcliffe coefficient (NSE), the ratio of the root-mean-square error to the standard deviation of measured data (RSR), and the percent of bias (PBIAS) [38]. These performance indicators are widely used in hydrologic and statistical modeling of environmental data [39-43]. A model's performance for streamflow is considered to be satisfactory when $\mathrm{R}^{2}$ and NSE are greater than 0.5 , RSR is less than 0.7 , and PBIAS ranges between less than $\pm 25 \%$. The calibrated and the validated SWAT hydrological model was then run for the period 1960-2008.

\subsection{MIKE HYDRO Basin Model}

MIKE HYDRO Basin has been applied to a large number of watersheds around the world with different climates and hydrological regimes [44-47]. MIKE HYDRO Basin has been used to simulate the components of the rainfall-runoff process (overland flow, interflow, and baseflow) [45,48], predict the impacts of climatic changes on habitat conservation of the endangered pearl mussel [49], estimate the nutrient loads from diffuse and point sources in river water [50,51], estimate the concentration of phosphorus in a river due to recurrent wildfires [52], and estimate the water availability for a population in climate change scenarios $[47,53]$.

The MIKE HYDRO Basin model is composed of catchment, river network, water user, and reservoir operation, including hydropower, elements. The river network includes branches, river links, river nodes, priority nodes, and routing. The water users include a regular water user and an irrigation water user. Into the regular water user module was input the amount of water used for domestic consumption, which was calculated using the resident population and the water consumption per municipality. Data on the resident population per year between 1960 and 2008 are available from the National Statistics Institute (INE) [19]. Data on water consumption between 1995 and 2009 per municipality (Table 1) are available from PORDATA [20]. These data are expressed in $\mathrm{L} \cdot$ day $^{-1} \cdot$ inhabitant $^{-1}$, and we used the average daily consumption per municipality to calculate the water consumption (Table 1).

The irrigation water user represents an irrigation area that comprises one or more irrigated crops and the total water requirements for the fields. The water requirements can be extracted from one or more sources, e.g., river nodes and/or reservoirs, according to specific allocation rules. The crop water requirement is defined as the amount of water that is required to compensate for the evapotranspiration loss (ET) from the cropped field and depends on the local climate and the crops growing in the fields. It is computed, according to the dual crop coefficient model approach, as follows [54]:

$$
E T_{c}=\left(K_{c b}+K_{e}\right) E T_{0}
$$

where $E T_{c}$ is the crop or maximum evapotranspiration $\left(\mathrm{mm} \cdot \mathrm{day}^{-1}\right)$ under the potential growing conditions with no soil water shortage stress, $K_{c b}$ is the basal crop coefficient that describes crop 
transpiration, $K_{e}$ is the soil water evaporation coefficient that describes soil evaporation, and $E T_{0}$ is the reference evapotranspiration value, which is calculated using the Penman-Monteith equation.

The irrigation module follows the methodology proposed by the Food and Agriculture Organization of the United Nations FAO-56 Dual Crop Coefficient, which concerns the parameters to be assigned to the crop model [54]. The irrigation module includes the crop data (crop-specific details), the irrigation method (how and when irrigation occurs), and the soil type. The crop data comprise a set of parameters, namely: crop stages, sowing date, basal crop coefficient $\left(K_{c b}\right)$, root depth, maximum height, and depletion fraction. Crop stages are divided into an initial stage, a development stage, a mid-season stage, and a late-season stage, and the periods are given in days. The basal crop coefficient $\left(K_{c b}\right)$ is defined as the crop evapotranspiration over the reference evapotranspiration $\left(E T_{d} / E T_{0}\right)$ when the soil surface is dry but transpiration is occurring at the potential rate, i.e., water is not limiting transpiration [54]. The root depth is specific to the initial and middle stages, and the depletion fraction is an average fraction of the total available soil water that can be depleted from the root zone before moisture stress. The parameters' values are provided by the FAO tables [54] and are shown for the crops identified in the Sabor River basin in Table 4.

Table 4. Crop parameters of the Sabor River basin that were input into MIKE HYDRO Basin and provided by the FAO tables [54]. The parameters include the crop stages, sowing date, basal crop coefficient $\left(K_{c b}\right)$, root depth, maximum height, and depletion fraction for each crop. Descriptions of the parameters can be found at http://www.fao.org/.

\begin{tabular}{|c|c|c|c|c|c|c|c|}
\hline Parameters & Maize & Potato & Vineyards & Olive Groves & Fruit Trees & Forages & Horticulture \\
\hline \multicolumn{8}{|l|}{$\begin{array}{c}\text { Crop stages } \\
\text { (days) }\end{array}$} \\
\hline Initial & 30 & 30 & 30 & 30 & 35 & 10 & 23 \\
\hline Development & 40 & 35 & 60 & 90 & 60 & 20 & 33 \\
\hline Middle & 50 & 50 & 40 & 60 & 110 & 144 & 39 \\
\hline Late & 30 & 30 & 80 & 90 & 61 & 23 & 21 \\
\hline Sowing date & 1-Apr & 1-Apr & 21-Feb & 1-Mar & 1-Mar & 15-Oct & 1-Apr \\
\hline \multicolumn{8}{|l|}{$K_{c b}$} \\
\hline$K_{c b}$ initial & 0.15 & 0.15 & 0.15 & 0.55 & 0.47 & 0.3 & 0.15 \\
\hline$K_{c b}$ middle & 1.15 & 1.1 & 0.65 & 0.65 & 0.76 & 0.7 & 1.02 \\
\hline$K_{c b}$ late & 0.33 & 0.65 & 0.4 & 0.65 & 0.64 & 0.7 & 0.72 \\
\hline $\begin{array}{l}\text { Maximum } \\
\text { height (m) }\end{array}$ & 2 & 0.6 & 1.75 & 4 & 3.67 & 0.31 & 0.45 \\
\hline \multicolumn{8}{|l|}{ Root depth } \\
\hline Initial (m) & 0.3 & 0.3 & 1 & 1 & 1 & 0.3 & 0.25 \\
\hline Middle (m) & 1 & 0.4 & 1.5 & 1.45 & 1.45 & 0.65 & 0.56 \\
\hline $\begin{array}{l}\text { Depletion } \\
\text { fraction }(p)\end{array}$ & 0.55 & 0.35 & 0.45 & 0.65 & 0.51 & 0.54 & 0.42 \\
\hline
\end{tabular}

The irrigation methods considered were the sprinkler method and the gravity irrigation and drip irrigation method. The sprinkler method was used for the maize, potato, forages, and horticulture crops, and the drip irrigation method was used for the vineyard, olive grove, and fruit tree crops. For each method, the spray loss and wetting fraction were defined. The spray loss corresponds to the fraction of the irrigation water that is evaporated before the water reaches the soil surface. The wetting fraction determines the fraction of the field surface that is being wetted during irrigation. The wetting fraction is an important factor for determining how much irrigation is required before the surface soil's storage is filled and, hence, when the root zone starts to fill. For the sprinkler method crops, we adopted a spray loss of 0.25 and a wetting fraction of 1 . For the drip irrigation method crops, we adopted a value of 0.1 for both the spray loss and the wetting fraction, except for the fruit tree crops, for which we adopted a spray loss of 0.15 and a wetting fraction of 0.25 . 
According to the 2009-2011 National Agricultural Census [18], in the Trás-os-Montes region, $70 \%$ of the water that is used for irrigation comes from groundwater sources, and the remainder comes from surface flow. Since the Sabor River basin is located in the Trás-os-Montes region, we applied these percentages to the water sources.

The dominant soil type in the basin is sandy loam ( $63.4 \%$ sand, $22.8 \%$ silt, and $14.8 \%$ clay). The sandy loam parameters and their respective values were: field capacity (0.2), wilting point (0.1), initial soil moisture (0.1), depth of evaporable layer (0.1), and porosity (0.45). The parameter values were obtained from the FAO tables [54].

\subsection{The MIKE HYDRO Basin Model Input and Output Data}

The MIKE HYDRO Basin model is composed of 37 sub-basins and rivers. For each sub-basin, we added a regular water user and an irrigation user (Figure 3a). SWAT was used to delimit the 37 sub-basins and rivers and obtain a time series of surface runoff and aquifer recharge. Into each regular water user was input the water consumption, and into each irrigation user was input a time series of precipitation and the reference evapotranspiration. All time series were input into each of the sub-basins, on a daily basis, between 1960 and 2008. Figure 3a shows each sub-basin's number, and Figure $3 b$ shows the name of each river.

The output of the model is presented for each catchment, node, and river of the basin. The values extracted from the nodes were the quantities of the streamflow and water used for domestic consumption and irrigation. For irrigation, the values of irrigation demand, applied irrigation, and deficit irrigation per sub-basin are available. The irrigation demand (expressed in $\mathrm{m}^{3} \cdot \mathrm{km}^{-2}$ per crop) was compared with a reference irrigation allocation. The irrigation demand, applied irrigation, and deficit irrigation (expressed in $\mathrm{m}^{3}$ for all crops for each sub-basin) were used to analyze the amount of water consumed, the amount of water required to irrigate the crops, and the water deficit of the crops, respectively. The streamflow, the water used for domestic consumption, the applied irrigation, and the deficit irrigation were expressed in $\mathrm{m}^{3} \cdot \mathrm{s}^{-1}$ in order to construct distribution maps.
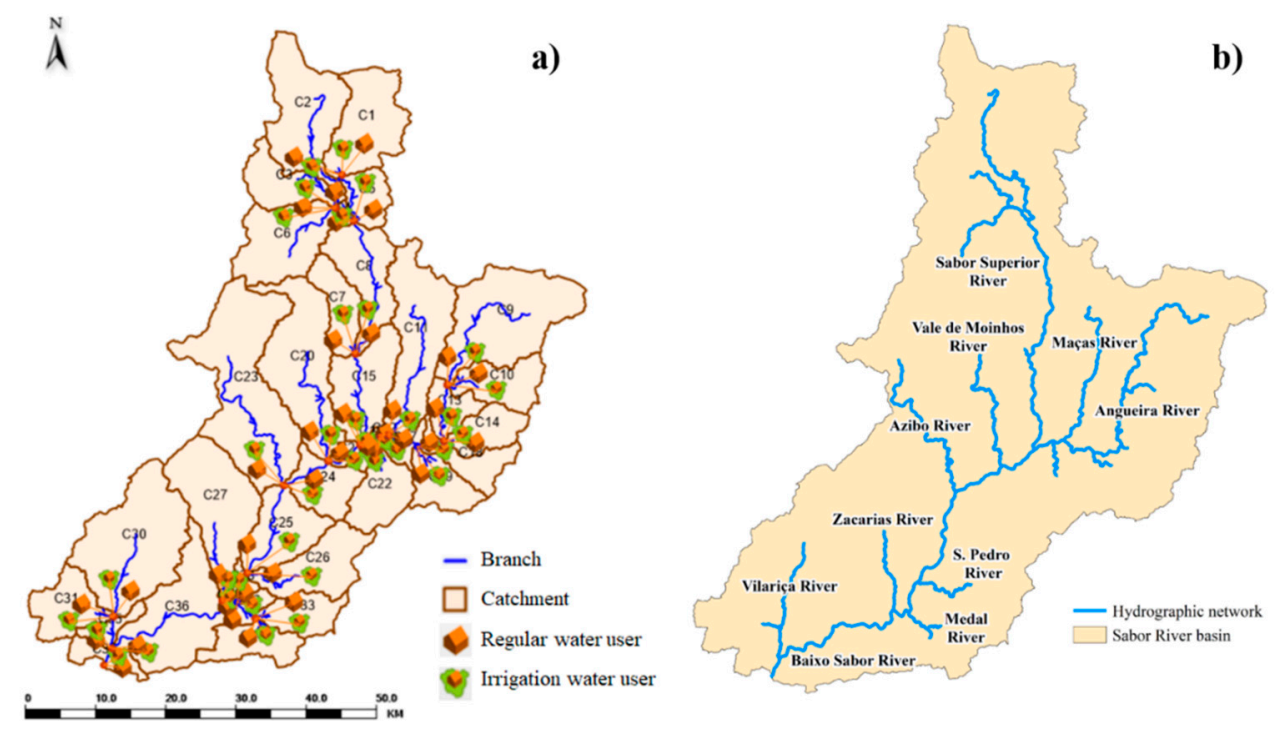

Figure 3. (a) The drainage networks, regular water users, and irrigation users at sub-basin scale in MIKE HYDRO Basin and (b) all tributaries of the Sabor River basin.

The applied irrigation in the basin was compared with a reference irrigation allocation from the Directorate-General for Agriculture and Rural Development (DGARD) [55] and Statistics Portugal (National Statistics Institute, INE) [17] for each crop. The reference irrigation allocation from DGARD is for the Northern and Central Interior Region of Portugal, and the reference irrigation allocation from the INE is for Portugal. The DGARD provides a reference irrigation allocation for groundwater 
and for different surface irrigation methods (sprinkler, micro-sprinkler, cannon, and drip irrigation). In this study, the average of the sprinkler, micro-sprinkler, and cannon irrigation methods was used for the maize, potato, forages, and horticulture crops, and drip irrigation was used for the vineyard, olive grove, and fruit tree crops. The reference irrigation allocation from DGARD and the INE for the olive grove, fruit tree, forages, and horticulture crops was the average of the cultures that occurred in the study area. For example, the reference irrigation allocation of horticulture is the average of the tomato, onion, carrot, melon, and pea cultures. The calculations for the reference irrigation allocation are presented in the supplementary material, worksheet 2 .

\subsection{Historical View and Evolutionary Scenarios}

The historical view modelled the domestic water consumption and irrigation in the Sabor River basin between 1960 and 2008. The simulation used the percentage of irrigated area per crop shown in Table 2 . The values of irrigated area per sub-basin can be found in supplementary material, worksheet 3. The areas were input into each sub-basin in the irrigation module of MIKE HYDRO Basin.

In the first scenario, we modelled the domestic water consumption with a time series of surface runoff, aquifer recharge, precipitation, and reference evapotranspiration data for the period 1960-2008. In the irrigation module, we assumed that the entire irrigable area identified in COS2007 was irrigated [21] (Table 2). The area of each irrigable crop per sub-basin can be found in the supplementary material, worksheet 4 .

In the second scenario, we modelled both a demographic projection and an irrigation projection for 2060 with a time series of surface runoff, aquifer recharge, precipitation, and reference evapotranspiration data for the period 1960-2008. The demographic projection was based on a projection scenario in a technical report on the resident population between 2012 and 2060 in the north zone and central region [56]. The projection estimates a $24 \%$ decrease in the resident population by 2060. Figure 4a shows the gradual reduction of the resident population from 2012 to 2060 for all municipalities in the Sabor River basin. The projection estimates a reduction of 25,056 inhabitants in municipalities of the basin by 2060, which means five less inhabitant $\cdot \mathrm{km}^{2}$. The municipalities with the largest projected reduction in population are Bragança and Macedo de Cavaleiros with 8495 and 3793 inhabitants, respectively. In the other municipalities, the reduction in population is projected to range between 910 and 2296 inhabitants.

The irrigation module was used to model the expansion of the olive grove area. According to the agricultural census [4-6] and the land use and land cover data for 2007 and 2015 [57], from 1989 to 2015 , the olive grove area increased by $86 \mathrm{~km}^{2}$ in the Sabor River basin (Figure $4 \mathrm{~b}$ ). The olive grove area's expansion was expressed using a robust linear regression $\left(R^{2}=0.97\right)$ and used to provide a projection on the olive grove area in 2060 (Figure $4 \mathrm{~b}$ ). The area is projected to expand by $172 \mathrm{~km}^{2}$, which represents a $29 \%$ increase.

A projection on the olive grove area's spatial distribution in 2060 was made according to land uses that had been converted into olive groves between COS2007 and COS2015. The main land uses in COS2007 that had been converted into olive groves in COS2015 were non-irrigated arable land, moors and heathland, transitional woodland-shrub, and eucalyptus forest. From these land uses, we randomly selected $29 \%$ of the area and assumed that, in 2060 , it will be olive groves. The olive grove area's expansion per sub-basin can be found in the supplementary material, worksheet 5 . 

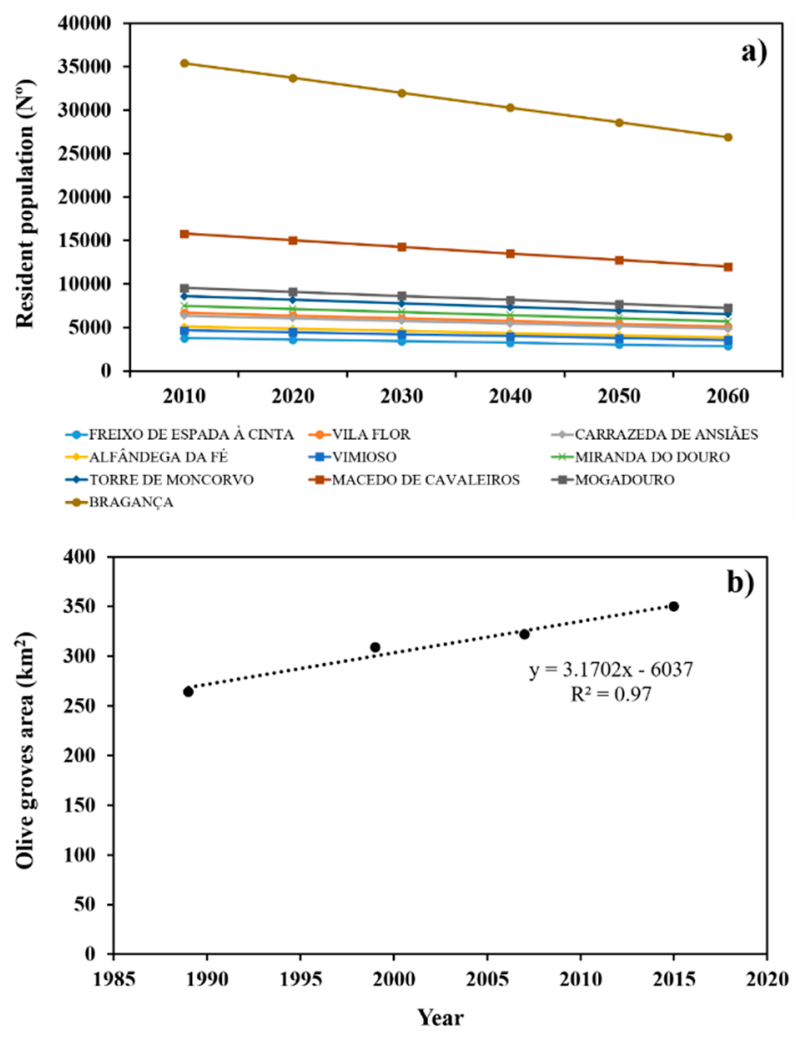

Figure 4. (a) Scenario for the resident population's evolution from 2010 to 2060 for municipalities in the Sabor River basin, and (b) Linear regression of the olive grove area between 1989 and 2015. The linear regression was used to make a projection on the olive grove area in 2060. Data on the resident population are from Statistics Portugal [19]. Data on the olive grove area are from the Directorate-General for Agriculture and Rural Development [4-6] and the Directorate-General of Territory [14].

\section{Results}

\subsection{Calibration and Validation of the Streamflow}

SWAT was used to simulate the daily streamflow in the Sabor River basin over 49 years (1960-2008). The streamflow was first calibrated to a 39-year period (1960-1999) and then validated to a 9-year period (2000-2008). The goodness-of-fit indicators from Table 5 indicate that the model's performance is satisfactory according to the model evaluation guidelines by Moriasi et al. [38].

Table 5. The goodness-of-fit indicators for the calibration, at a daily time-step for the period 1960-1999, and the validation, for the period 2000-2008, of streamflow in the Sabor River basin. Symbols: $\mathrm{R}^{2}$ - coefficient of determination, NSE-Nash-Sutcliffe coefficient, RSR - the ratio of the root mean square error to the standard deviation of measured data, and PBIAS - the percent of bias.

\begin{tabular}{ccccc}
\hline Measure & Calibration & Acceptable Ranges & Validation & Acceptable Ranges \\
\hline $\mathrm{R}^{2}$ & 0.63 & $>0.5$ acceptable [38] & 0.80 & $>0.75$ very good [38] \\
RSR & 0.62 & Satisfactory [38] & 0.63 & Satisfactory [38] \\
NS & 0.62 & Satisfactory [38] & 0.61 & Satisfactory [38] \\
PBIAS & $2.7 \%$ & Very good [38] & $-24 \%$ & Satisfactory [38] \\
\hline
\end{tabular}

The streamflow's calibration shows a satisfactory performance with $\mathrm{R}^{2}$, RSR, and NS values of 0.63 , 0.62 , and 0.62 , respectively, and a very good PBIAS (2.7\%) [38]. The same goodness-of-fit indicators were obtained for the validation, with a very good $\mathrm{R}^{2}(0.8)$ and satisfactory RSR, NS, and PBIAS values $(0.63,0.61$, and $-24 \%$, respectively) (Table 5). The negative PBIAS value indicates a model overestimation bias [38]. Figure 5a,b illustrate the calibrated and validated streamflow, respectively. 
As shown in the figures, there is good agreement between the observed and the simulated streamflow. The parameters and their respective values that resulted from the calibration in SWAT-CUP can be found in Santos et al. [36].
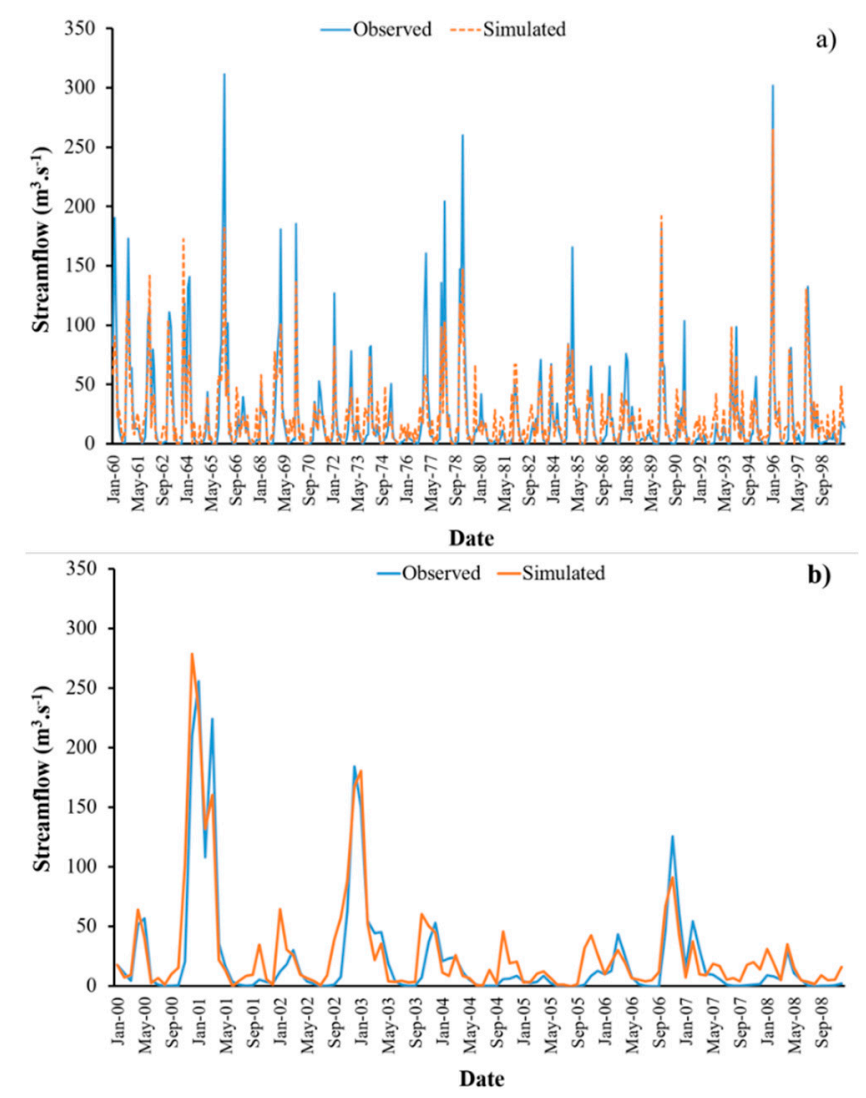

Figure 5. Comparison of observed and simulated streamflow during (a) the calibration period (1960-1999); and (b) the validation period (2000-2008) in the Sabor River basin. The simulation of the streamflow was executed on a daily basis; however, for the sake of visualization, the results are presented on a monthly basis.

Figure $6 \mathrm{a}, \mathrm{b}$ shows the average values of streamflow and precipitation, respectively. The streamflow is represented at the sub-basin scale and for the period 1960-2008. The streamflow over most of the basin's surface is less than $40 \times 10^{6} \mathrm{~m}^{3}$ of water. The greatest values were recorded in the Azibo river $\left(94 \times 10^{6} \mathrm{~m}^{3}\right)$, followed by the Vale of Moinhos, upstream of the Baixo Sabor and Zacarias rivers, with values that ranged between 41 and $54 \times 10^{6} \mathrm{~m}^{3}$ (Figures $3 \mathrm{~b}$ and $6 \mathrm{a}$ ). The obtained precipitation values are based on the spatial interpolation of data from the meteorological stations used in SWAT to construct the hydrological model. The interpolation shows that the highest values were recorded in the sub-basins located in the west of the basin, with values that ranged between 800 and $1137 \mathrm{~mm}$ (Figure 6b). 

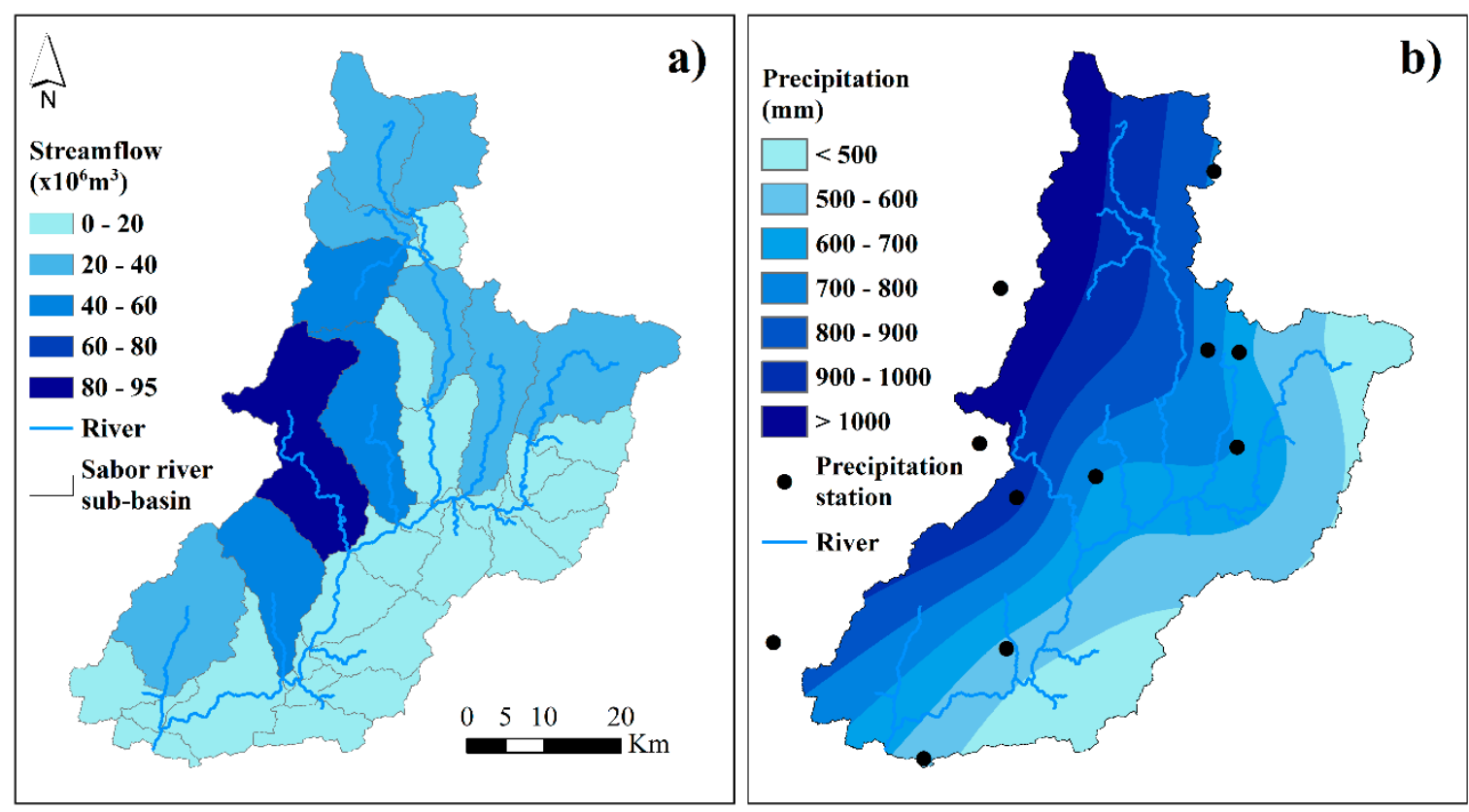

Figure 6. The streamflow and precipitation in the Sabor River basin. (a) The streamflow is an annual average value for the period 1960-2008 and is represented at the sub-basin scale. (b) The precipitation is based on the spatial interpolation of data from the meteorological stations used in SWAT to construct the hydrological model, with values for the period 1960-2008.

\subsection{Irrigation Demand}

The simulation of irrigation demand was performed on a daily basis, at the sub-catchment scale, between 1960 and 2008 in the Sabor River basin. Table 6 presents the results of the irrigation demand simulation by the MIKE HYDRO Basin irrigation scheme and the reference irrigation allocation for each crop. The irrigation demand represents the average annual water consumption of each crop in the basin. The maize, potato, and fruit tree crops had the highest water resource requirements (an average allocation higher than $5300 \mathrm{~m}^{3} \cdot \mathrm{ha}^{-1}$ ). The horticulture crop also had a high water allocation requirement (approximately $\left.4500 \mathrm{~m}^{3} \cdot \mathrm{ha}^{-1}\right)$, followed by forages $\left(3475 \mathrm{~m}^{3} \cdot \mathrm{ha}^{-1}\right)$. Vineyards and olive groves had the lowest water resource requirements of the analyzed crops (2436 and $2783 \mathrm{~m}^{3} \cdot \mathrm{ha}^{-1}$, respectively).

These results fall within the range of irrigation allocation reference values given by the Directorate-General for Agriculture and Rural Development for the Northern and Central Interior Region of Portugal [55] and Statistics Portugal for Portugal [17] (Table 6). The irrigation allocation reference values, per crop and irrigation method, can be found in the supplementary material, worksheet 3 . The irrigation demand for potato and olive groves falls into the range of reference values. The irrigation demand for fruit trees and horticulture is close to the minimum reference value (5817 and $4514 \mathrm{~m}^{3} \cdot \mathrm{ha}^{-1}$, respectively). The irrigation demand for forages $\left(3475 \mathrm{~m}^{3} \cdot \mathrm{ha}^{-1}\right)$ was the farthest from the minimum reference value $\left(4213 \mathrm{~m}^{3} \cdot \mathrm{ha}^{-1}\right)$. The irrigation demand for vineyards is close to the maximum reference value $\left(2302 \mathrm{~m}^{3} \cdot \mathrm{ha}^{-1}\right)$. 
Table 6. The irrigation demand in the Sabor River basin and the reference irrigation allocation for each crop. The simulation was performed at the sub-catchment scale and for the period 1960-2008. The reference irrigation allocation for each crop was obtained from the Directorate-General for Agriculture and Rural Development (DGARD) [55] and Statistics of Portugal (National Statistics Institute, INE) [17]. The DGARD provides a reference irrigation allocation for groundwater and for different surface irrigation methods. We used an average of the sprinkler, micro-sprinkler, and cannon irrigation methods for the maize, potato, forages, and horticulture crops, and the drip irrigation method was used for the vineyard, olive grove, and fruit tree crops. The reference irrigation allocation from (DGARD) is for the Northern and Central Interior Region of Portugal, and the reference irrigation allocation from Statistics Portugal is for Portugal.

\begin{tabular}{|c|c|c|c|c|c|}
\hline \multirow{2}{*}{$\begin{array}{l}\text { Irrigated } \\
\text { Crops }\end{array}$} & \multirow{2}{*}{$\begin{array}{c}\begin{array}{c}\text { Sabor River } \\
\text { Basin }\end{array} \\
\begin{array}{c}\text { Irrigation } \\
\text { Demand } \\
\left(\mathrm{m}^{3} \cdot \mathrm{ha}^{-1}\right)\end{array}\end{array}$} & \multicolumn{3}{|c|}{ DGARD } & \multirow{2}{*}{$\begin{array}{c}\text { INE } \\
\begin{array}{l}\text { Irrigation } \\
\left(\mathrm{m}^{3} \cdot \mathrm{ha}^{-1}\right)\end{array}\end{array}$} \\
\hline & & $\begin{array}{c}\text { Sprinkler, } \\
\text { Micro-Sprinkler and } \\
\text { Cannon }\left(\mathrm{m}^{3} \cdot \mathrm{ha}^{-1}\right)\end{array}$ & $\underset{\left(\mathrm{m}^{3} \cdot \mathrm{ha}^{-1}\right)}{\text { Drip }}$ & $\begin{array}{l}\text { Groundwater } \\
\left(\mathrm{m}^{3} \cdot \mathrm{ha}^{-1}\right)\end{array}$ & \\
\hline Maize & 5308 & 9163 & & 7546 & 6177 \\
\hline Potato & 5335 & 5484 & & 4712 & 7385 \\
\hline Vineyards & 2436 & & 2281 & 2147 & 2302 \\
\hline Olive groves & 2783 & & 2919 & 2748 & 2259 \\
\hline Fruit trees & 5620 & & 6482 & 6100 & 5817 \\
\hline Forages & 3475 & 5115 & & 4213 & 8823 \\
\hline Horticulture & 4496 & 5404 & & 4514 & 5574 \\
\hline
\end{tabular}

\subsection{Historical View and Evolutionary Scenarios of Domestic Consumption and Irrigation}

Table 7 shows the total water demand, the water used, and the water demand deficit for domestic consumption in the Sabor River basin. The values are expressed as the annual average in the period 1960-2008 for the historical view and for the two scenarios (the increase in irrigated area and the $29 \%$ increase in Olive grove area in 2060). The total water demand in the historical view, and in the increase in irrigated area scenario, was $1372 \times 10^{3} \mathrm{~m}^{3}$. The total water demand in the scenario of a $29 \%$ increase in the Olive grove area in 2060 was $1045 \times 10^{3} \mathrm{~m}^{3}$. The water used for domestic consumption in the historical view was $950 \times 10^{3} \mathrm{~m}^{3}$ and was decreased in both the scenario of an increase in the irrigated area and the scenario of a $29 \%$ increase in the Olive grove area in $2060\left(866\right.$ and $659 \times 10^{3} \mathrm{~m}^{3}$, respectively). The water demand deficit in the historical view was $422 \times 10^{3} \mathrm{~m}^{3}(31 \%)$. It increased in the scenario of an increase in the irrigated area $\left(506 \times 10^{3} \mathrm{~m}^{3}\right)$, and decreased in the 2060 projection scenario $\left(385 \times 10^{3} \mathrm{~m}^{3}\right)$. In both scenarios, the water deficit was $37 \%$.

In the historical view, the annual irrigation demand for all crops was calculated to be $94 \times 10^{6} \mathrm{~m}^{3}$ for $181.6 \mathrm{~km}^{2}$ of the irrigated area (Table 8 ). Fruit trees were found to have the highest irrigation demand $\left(53.7 \times 10^{6} \mathrm{~m}^{3}\right)$, followed by maize and potato $\left(14.1 \times 10^{6} \mathrm{~m}^{3}\right.$ and $12.8 \times 10^{6} \mathrm{~m}^{3}$, respectively). Forages $\left(0.03 \times 10^{6} \mathrm{~m}^{3}\right)$ and vineyards $\left(0.75 \times 10^{6} \mathrm{~m}^{3}\right)$ were found to have the lowest irrigation demand. The irrigation demand for olive groves and horticulture was $6.2 \times 10^{6} \mathrm{~m}^{3}$ and $6.6 \times 10^{6} \mathrm{~m}^{3}$, respectively. However, only $28.8 \times 10^{6} \mathrm{~m}^{3}$ of water was found to have been applied, which represents an irrigation deficit of $65.4 \times 10^{6} \mathrm{~m}^{3}$ for all crops. The irrigation deficit ranges between $50 \%$ and $68 \%$ of the plants' water requirements. As expected, the highest irrigation deficit was calculated for the crops with the highest irrigation demand, such as fruit trees, maize, and potato $\left(37.6,10\right.$, and $9 \times 10^{6} \mathrm{~m}^{3}$, respectively).

In the first scenario, we assumed that the entire irrigable area was irrigated $\left(586.8 \mathrm{~km}^{2}\right)$. The aim is to determine the quantity of water that is necessary to satisfy each crop's water demand. The results show that $237 \times 10^{6} \mathrm{~m}^{3}$ of annual irrigation is needed to satisfy the water requirements of all of the crops (Table 8). The highest irrigation demand was calculated for olive groves and fruit trees $\left(91.22 \times 10^{6} \mathrm{~m}^{3}\right.$ and $81.33 \times 10^{6} \mathrm{~m}^{3}$, respectively). Forages were found to have the lowest irrigation demand $\left(0.64 \times 10^{6} \mathrm{~m}^{3}\right)$. With respect to the other crops, the irrigation demand ranged between 11 and $18 \times 10^{6} \mathrm{~m}^{3}$. However, only $54.7 \times 10^{6} \mathrm{~m}^{3}$ of irrigation was found to have been applied, which 
represents an irrigation deficit of $182.5 \times 10^{6} \mathrm{~m}^{3}$ for all crops. The irrigation deficit ranges between $55.4 \%$ and $78 \%$ of the plants' water requirements. As expected, the highest irrigation deficit was calculated for the crops with the highest irrigation demand, such as olive groves and fruit trees (69.3 and $63.6 \times 10^{6} \mathrm{~m}^{3}$, respectively).

Table 7. The average annual quantity of used water and the water demand deficit (for domestic consumption) simulated in the Sabor River Basin for the historical view (1960-2008), and for the two scenarios (an increase in the irrigated area and the projection to 2060). The scenario of an increase in the irrigated area represents the irrigation of the total irrigable area identified in Continental Portugal for 2007 (COS2007) [21].

\begin{tabular}{|c|c|c|c|c|}
\hline \multirow{2}{*}{ Historical View/Scenarios } & \multirow{2}{*}{$\begin{array}{l}\text { Total Water Demand } \\
\qquad\left(10^{3} \mathrm{~m}^{3}\right)\end{array}$} & \multirow{2}{*}{$\begin{array}{l}\text { Used Water } \\
\left(10^{3} \mathrm{~m}^{3}\right)\end{array}$} & \multicolumn{2}{|c|}{ Water Demand Deficit } \\
\hline & & & $\left(10^{3} \mathrm{~m}^{3}\right)$ & $\%$ \\
\hline Historical view from 1960 to 2008 & 1372.27 & 950.47 & 421.8 & 31 \\
\hline The scenario of increase of irrigated area & 1372.27 & 866.42 & 505.62 & 37 \\
\hline Scenario of projection to 2060 & 1044.5 & 659.33 & 385.15 & 37 \\
\hline
\end{tabular}

Table 8. The average annual irrigation demand, applied irrigation, and irrigation deficit per crop in the Sabor River Basin for the historical view (from 1960 to 2008) and for the two scenarios (an increase in the irrigated area and a projection to 2060). The scenario of an increase in the irrigated area represents the irrigation of the total irrigable area identified in COS2007 [21].

\begin{tabular}{|c|c|c|c|c|c|}
\hline \multirow{2}{*}{$\begin{array}{l}\text { Irrigated } \\
\text { Crops }\end{array}$} & \multirow{2}{*}{ Area $\left(\mathrm{km}^{2}\right)$} & \multirow{2}{*}{$\begin{array}{c}\text { Irrigation } \\
\text { Demand }\left(10^{6} \mathrm{~m}^{3}\right)\end{array}$} & \multirow{2}{*}{$\begin{array}{l}\text { Applied Irrigation } \\
\qquad\left(10^{6} \mathrm{~m}^{3}\right)\end{array}$} & \multicolumn{2}{|c|}{ Irrigation Deficit } \\
\hline & & & & $\left(10^{6} \mathrm{~m}^{3}\right)$ & $\%$ \\
\hline \multicolumn{6}{|c|}{ Historical view from 1960 to 2008} \\
\hline Maize & 25.7 & 14.08 & 4.14 & 9.94 & 67.2 \\
\hline Potato & 22.8 & 12.77 & 3.7 & 9.06 & 67.8 \\
\hline Vineyards & 3 & 0.75 & 0.3 & 0.45 & 56.6 \\
\hline Olive groves & 22.5 & 6.18 & 2.34 & 3.84 & 57.2 \\
\hline Fruit trees & 91.5 & 53.68 & 16.09 & 37.59 & 65.1 \\
\hline Forages & 0.1 & 0.03 & 0.02 & 0.01 & 50.5 \\
\hline Horticulture & 15.9 & 6.64 & 2.13 & 4.51 & 64.5 \\
\hline Total & 181.6 & 94.13 & 28.71 & 65.41 & 69.5 \\
\hline \multicolumn{6}{|c|}{ The scenario of increase of irrigated area } \\
\hline Maize & 28.5 & 17.7 & 3.98 & 13.72 & 77.5 \\
\hline Potato & 28.5 & 18.1 & 4 & 14.12 & 77.9 \\
\hline Vineyards & 43 & 11 & 2.7 & 8.27 & 75.4 \\
\hline Olive groves & 322 & 91.22 & 21.93 & 69.29 & 76 \\
\hline Fruit trees & 131 & 81.33 & 17.78 & 63.55 & 78.1 \\
\hline Forages & 1.8 & 0.64 & 0.28 & 0.35 & 55.4 \\
\hline Horticulture & 32 & 17.26 & 4.05 & 13.22 & 76.6 \\
\hline Total & 586.8 & 237.2 & 54.71 & 182.5 & 76.9 \\
\hline \multicolumn{6}{|c|}{ The scenario of projection to 2060} \\
\hline Maize & 25.7 & 15.38 & 3.74 & 11.63 & 77.6 \\
\hline Potato & 22.8 & 13.97 & 3.34 & 10.63 & 78.1 \\
\hline Vineyards & 3 & 0.77 & 0.20 & 0.57 & 69.8 \\
\hline Olive groves & 494 & 140.08 & 33.10 & 106.98 & 70.6 \\
\hline Fruit trees & 91.5 & 56.74 & 12.67 & 44.07 & 76 \\
\hline Forages & 0.1 & 0.03 & 0.01 & 0.02 & 56.8 \\
\hline Horticulture & 15.9 & 8.34 & 2.11 & 6.23 & 75.8 \\
\hline Total & 653 & 235.3 & 55.2 & 180 & 76.6 \\
\hline
\end{tabular}


In the second scenario, we projected a $140.1 \mathrm{~km}^{2}$ increase in the olive grove area for 2060. In this scenario, the irrigated area of all other crops is the same as that in the historical view period (1960-2008). The results show that $235.3 \times 10^{6} \mathrm{~m}^{3}$ of annual irrigation is needed to satisfy the water requirements of all of the crops (Table 8). For olive groves, only $33 \times 10^{6} \mathrm{~m}^{3}$ of irrigation was found to have been applied, which represents an irrigation deficit of $107 \times 10^{6} \mathrm{~m}^{3}$. The irrigation deficit was $70.6 \%$ of the crops' total water requirement. For all other crops, the irrigation demand, applied irrigation, and deficit irrigation were close to the values obtained for the historical view.

\subsection{Spatial Distribution of Water Allocation}

Figure 7 shows the spatial distribution of the water used for domestic consumption and the water demand deficit per sub-basin of the Sabor River basin. The values are the annual average between 1960 and 2008 for the historical view and for the two scenarios (an increase in the irrigated area and a projection to 2060). In the historical view (between 1960 and 2008) (Figure 7a,b), most of the basin's surface consumed between 22 and $58 \times 10^{3} \mathrm{~m}^{3}$ of water. The greatest water consumption was recorded in the Azibo river, the Vilariça river, and downstream of the Baixo Sabor river, with values that ranged between 62 and $95 \times 10^{3} \mathrm{~m}^{3}$ (Figure 7a). In terms of the water demand deficit, the highest values were recorded in the Azibo and Vilariça rivers $\left(44 \times 10^{3} \mathrm{~m}^{3}\right.$ and $46 \times 10^{3} \mathrm{~m}^{3}$, respectively) (Figure $7 \mathrm{~b}$ ).

In the scenario of an increase in the irrigated area (Figure 7c,d), most of the basin's surface is able to consume between 20 and $55 \times 10^{3} \mathrm{~m}^{3}$ of water, and the highest consumption of water occurs in the Azibo river $\left(87 \times 10^{3} \mathrm{~m}^{3}\right)$ (Figure $\left.7 \mathrm{c}\right)$. The highest water demand deficits occur in the Azibo, Vale de Moinhos, and Vilariça rivers with values that range between 41 and $54 \times 10^{3} \mathrm{~m}^{3}$ (Figure $7 \mathrm{~d}$ ).

In the projection to 2060 scenario (Figure 7e,f), most of the basin's surface is able to consume between 21 and $40 \times 10^{3} \mathrm{~m}^{3}$ of water, and the highest water consumption occurs in the Azibo river and upstream of the Douro Superior river $\left(66 \times 10^{3} \mathrm{~m}^{3}\right.$ and $46 \times 10^{3} \mathrm{~m}^{3}$, respectively) (Figure 7e). The water demand deficit is $20 \times 10^{3} \mathrm{~m}^{3}$ of water for most of the basin's surface. The highest deficits occur in the Azibo, Vale de Moinhos, Maças, and Vilariça rivers with values that range between 20 and 41 (Figure 7f).

Figure 8 shows the spatial distribution of the applied irrigation and the irrigation deficit per sub-basin of the Sabor River basin. The values are expressed as the annual average between 1960 and 2008 for the historical view and for the two scenarios (an increase in the irrigated area and a projection to 2060). In the historical view, the highest amounts of applied irrigation (Figure 8a) and irrigation deficits (Figure $8 b$ ) were found in rivers situated in the west of the basin, more precisely in the Sabor Superior river, the Vale of Moinhos, the Azibo river, the Zacarias river, and upstream of the Angueira river (Figure $3 \mathrm{~b}$ ). In these rivers, the quantity of applied irrigation ranged between 1.6 and $3.4 \times 10^{6} \mathrm{~m}^{3}$ of water and the irrigation deficit between 4.8 and $7.8 \times 10^{6} \mathrm{~m}^{3}$ of water.

In the scenario of an increase in the irrigated area (Figure $8 \mathrm{c}, \mathrm{d}$ ), the quantities of applied irrigation ranged between 0.01 and $3.9 \times 10^{6} \mathrm{~m}^{3}$ of water, except for in the Azibo river $\left(6.6 \times 10^{6} \mathrm{~m}^{3}\right.$ of water $)$ (Figure 8c). The irrigation deficit was highest in the Vale of Moinhos, the Azibo river, the Zacarias river, the Vilariça river, and downstream of the Baixo Sabor river, with values that ranged between 10.3 and $22 \times 10^{6} \mathrm{~m}^{3}$ of water (Figure $8 \mathrm{~d}$ ).

In the projection to 2060 scenario (Figure $8 \mathrm{e}, \mathrm{f}$ ), the quantities of applied irrigation ranged between 0.01 and $4.1 \times 10^{6} \mathrm{~m}^{3}$ of water, except for in the Azibo river $\left(6.5 \times 10^{6} \mathrm{~m}^{3}\right.$ of water) (Figure $\left.8 \mathrm{e}\right)$. The irrigation deficit is highest in the Vale of Moinhos, the Azibo river, the Zacarias river, the Vilariça river, and downstream of the Baixo Sabor river, with values that range between 12.7 and $24 \times 10^{6} \mathrm{~m}^{3}$ of water (Figure $8 \mathrm{f}$ ). 

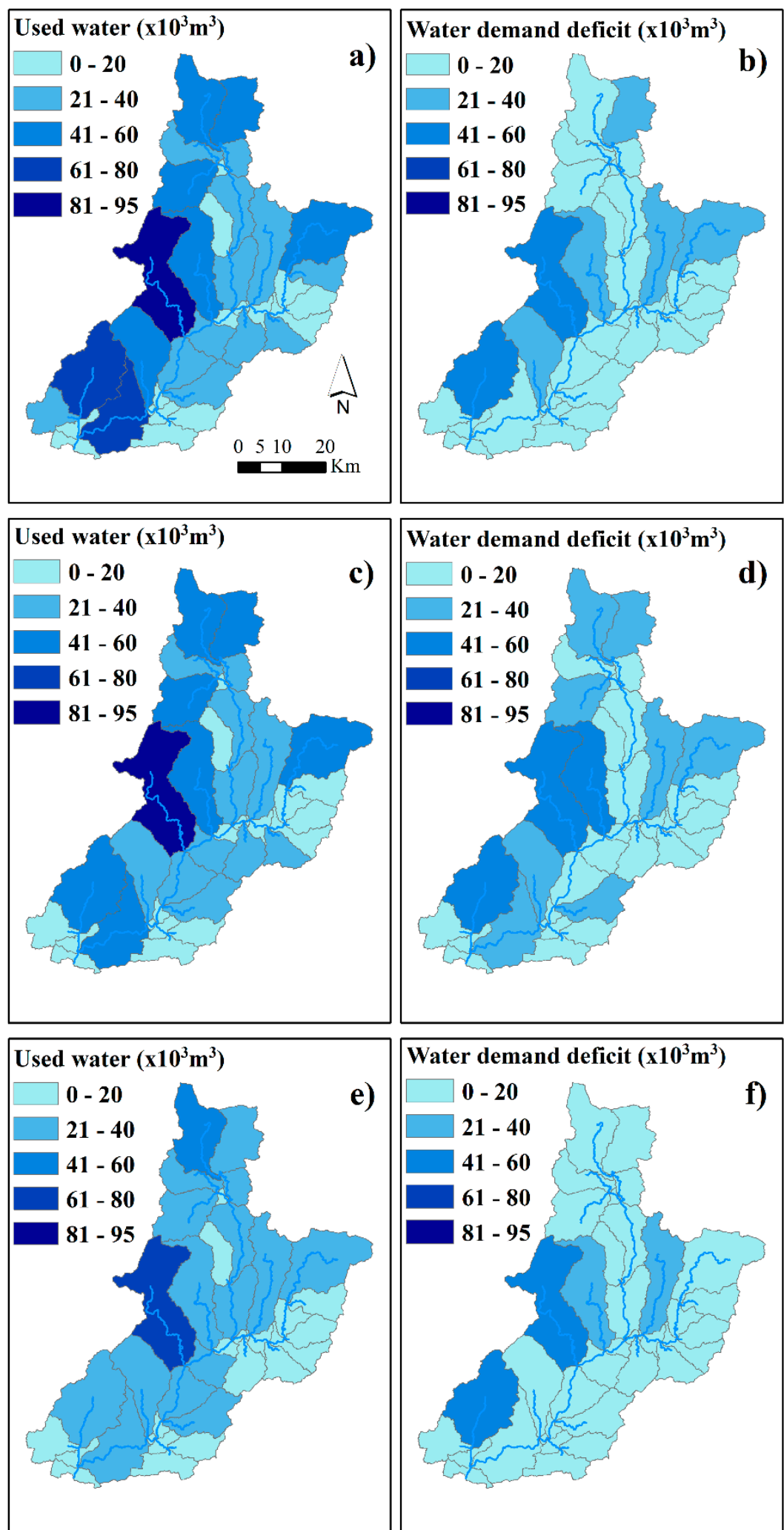

Water demand deficit $\left(\mathrm{x}^{10^{3}} \mathrm{~m}^{3}\right)$

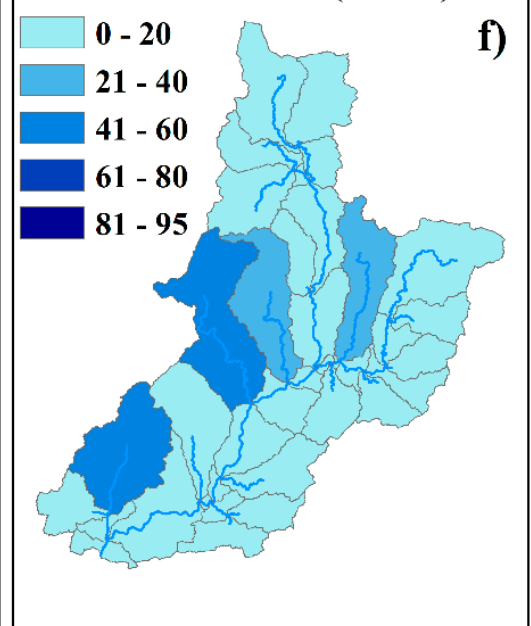

Figure 7. The water used for domestic consumption and the water demand deficit at the sub-basin scale in the Sabor River basin. (a) and (b) represent the water used for domestic consumption and the water demand deficit in the historical view, respectively. The figures (c) and (d) represent the data on the increase in the irrigated area, and (e) and (f) represent the data on the scenario of a projection to 2060. 

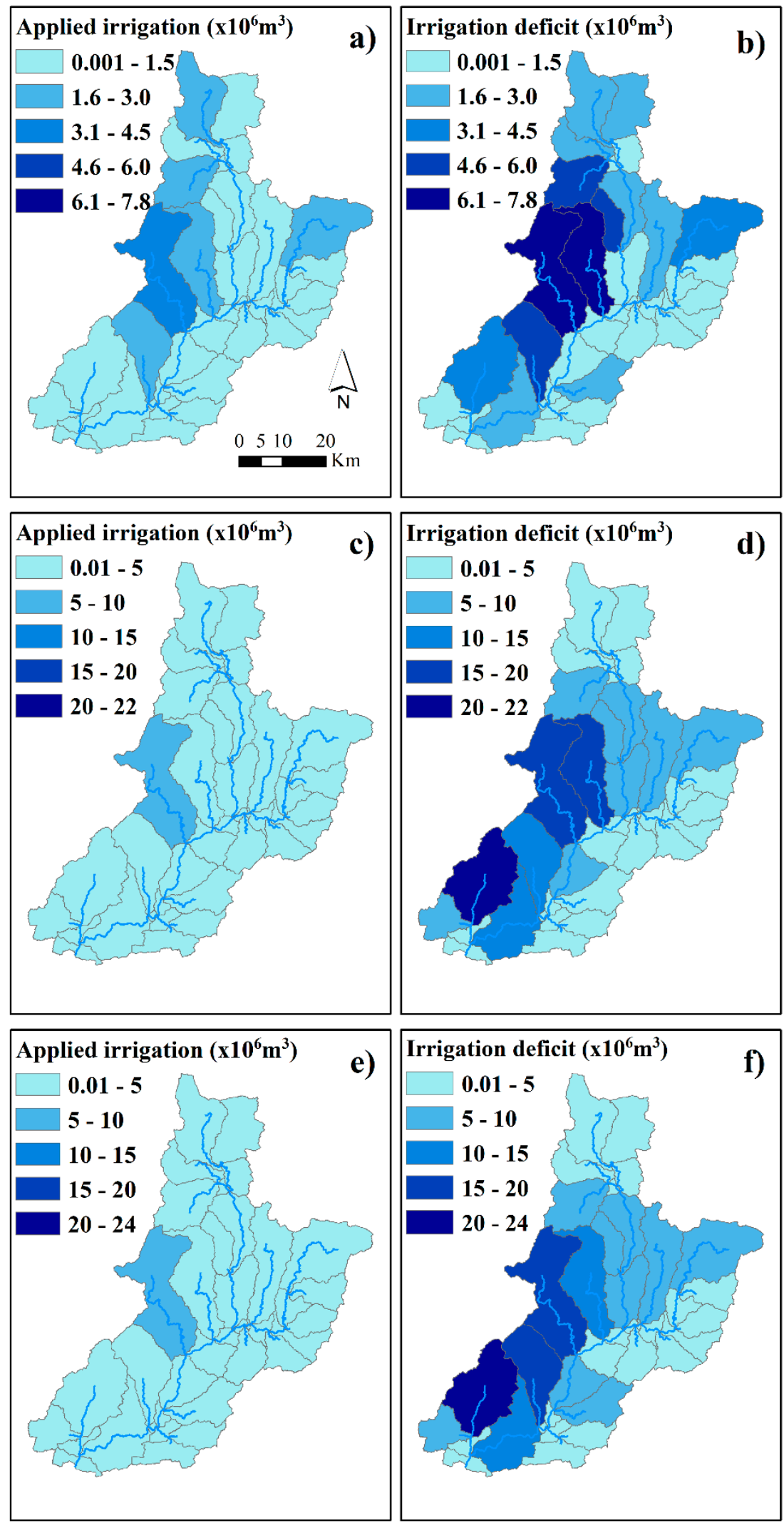

Figure 8. The applied irrigation and irrigation deficit at sub-basin scale in the Sabor River basin. (a) and (b) represent the applied irrigation and the irrigation deficit in the historical view, respectively. Figures (c) and (d) represent the data on the scenario of an increase in the irrigated area, and (e) and (f) represent the data on the scenario of a projection to 2060. 


\section{Discussion}

\subsection{Historical View of Water Allocation}

The annual average quantity of water that left the Sabor River basin during the period 1960-2008 was $629 \times 10^{6} \mathrm{~m}^{3}\left(\right.$ or $\left.20 \mathrm{~m}^{3} \cdot \mathrm{s}^{-1}\right)$. The domestic consumption of water is, on average, $0.15 \%$ of the total amount of water in the basin, and $0.22 \%$ of the total amount of water in the basin is necessary to meet all domestic water consumption needs (Table 7 and Figure 6a). However, irrigation consumes an annual average of $5 \%$ of the total amount of water in the basin, and $15 \%$ of the total amount of water in the basin is necessary to satisfy all irrigation demand. (Table 8 and Figure 6a). The water used for domestic consumption was $950 \times 10^{3} \mathrm{~m}^{3}$, and the water deficit was $422 \times 10^{3} \mathrm{~m}^{3}$ (Table 7). The annual irrigation demand was $94 \times 10^{6} \mathrm{~m}^{3}$, and the water demand deficit was $65.4 \times 10^{6} \mathrm{~m}^{3}$ (Table 8). The water demand deficit for domestic consumption was 31\%, and the water demand deficit for irrigation was $69.5 \%$. This high water demand deficit is due to the low flow period in spring and summer and the high variation in river flow during the year. Figure 9 shows the annual variation in total irrigation demand, applied irrigation, streamflow, precipitation, and evapotranspiration for the period 1960-2008. Critical periods of irrigation deficit occur in July and August because the total irrigation demand is higher than the streamflow. Between March and October, except for the critical periods, the streamflow is higher than the total irrigation demand. However, the applied irrigation is less than the total irrigation demand. This happened because, in most years, the river flow was low, and could not supply the irrigation demand. The low streamflow is a consequence of the low precipitation and high evaporation that Mediterranean countries experience during the spring and summer $[10,45,58]$.

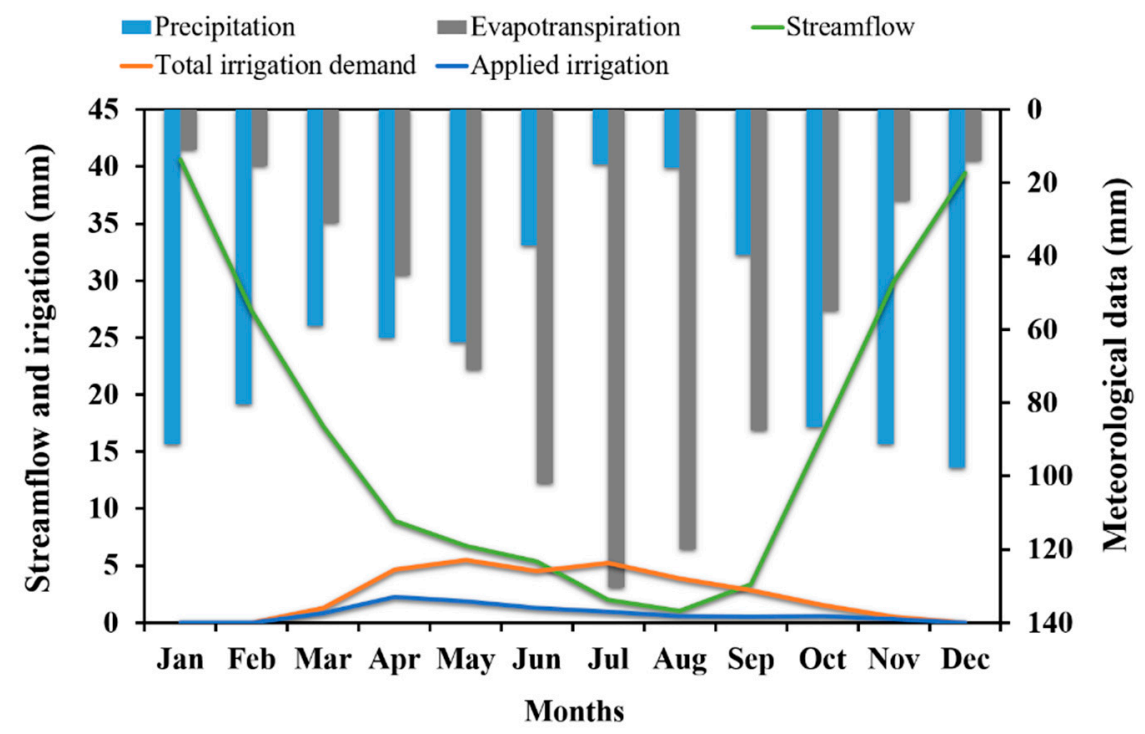

Figure 9. The streamflow, total irrigation demand, applied irrigation, precipitation, and evapotranspiration in the Sabor River basin for the period 1960-2008.

\subsection{Evolutionary Scenarios}

In the scenario of an increase in the irrigated area, we assumed that the total area of each crop was irrigated. In this scenario, we found that $237.2 \times 10^{6} \mathrm{~m}^{3}$ of water will be necessary to irrigate $586.8 \mathrm{~km}^{2}$ of crop area. If we consider the same streamflow between 1960 and 2008 , only $54.7 \times 10^{6} \mathrm{~m}^{3}$ of water is necessary for irrigation. The deficit will be $182.5 \times 10^{6} \mathrm{~m}^{3}$ of water, which represents $76.9 \%$ of the total irrigation demand (Table 8 ). The highest irrigation demand was calculated for olive groves $\left(91.22 \times 10^{6} \mathrm{~m}^{3}\right.$ of water $)$, and fruit trees $\left(81.33 \times 10^{6} \mathrm{~m}^{3}\right.$ of water). The water requirement for these crops is high because they occupy a large irrigated area (322 and $131 \mathrm{~km}^{2}$, respectively). These crops represent $77 \%$ of the irrigable area of the basin (Table 8 ). Moreover, the water deficit 
is higher: approximately $69.3 \times 10^{6} \mathrm{~m}^{3}$ and $64 \times 10^{6} \mathrm{~m}^{3}$ of water for olive groves and fruit trees, respectively. The quantity of water used for domestic consumption is $866 \times 10^{3} \mathrm{~m}^{3}$, and the water deficit is $506 \times 10^{3} \mathrm{~m}^{3}$, which represents $37 \%$ of the total water demand. The results show that, in this scenario, the increase in the water demand deficit of $84 \times 10^{3} \mathrm{~m}^{3}$ for domestic consumption, and of $117.1 \times 10^{6} \mathrm{~m}^{3}$ for irrigation, when compared to the historical view, is due to the increase in the irrigation area and the lower availability of water, especially in spring and summer.

In the scenario of a projection to 2060, the expansion of the olive grove area represents a $172 \mathrm{~km}^{2}$ increase in this crop's irrigable area. The scenario was projected with the streamflow for the period 1960-2008 and the irrigated area for the other crops that was reported in the historical view. In this scenario, $140.1 \times 10^{6} \mathrm{~m}^{3}$ of water will be necessary to irrigate $494 \mathrm{~km}^{2}$ of olive grove area, but only $33.1 \times 10^{6} \mathrm{~m}^{3}$ of water will be applied, which represents a deficit of $107 \times 10^{6} \mathrm{~m}^{3}$ of water. A total of $235.3 \times 10^{6} \mathrm{~m}^{3}$ of water will be necessary to irrigate the entire area (approximately $653 \mathrm{~km}^{2}$ ), but only $55.2 \times 10^{6} \mathrm{~m}^{3}$ of water will be applied to irrigation. The deficit will be $180 \times 10^{6} \mathrm{~m}^{3}$ of water, which represents $76.6 \%$ of the total irrigation demand (Table 8 ). The $24 \%$ decrease in the resident population by 2060 represents a reduction of 25,056 inhabitants and five less inhabitants $\cdot \mathrm{km}^{2}$ in the municipalities in the basin. This population reduction will produce a $327 \times 10^{3} \mathrm{~m}^{3}$ decrease in total water demand. However, a water demand deficit of $385 \times 10^{3} \mathrm{~m}^{3}$ will remain because of the increase in the olive grove irrigation area.

\subsection{Spatial Distribution}

The spatial distribution of the water used for domestic consumption and irrigation in the historical view and in both scenarios shows that the highest consumption of water occurred in the west of the basin (Figure 7). The reason for this is that the basin's western region has the highest population density ( $>20$ inhabitants $\cdot \mathrm{km}^{-2}$ ), which is responsible for the domestic water consumption (Figure 1b), and is a large irrigable area where olive groves and fruit trees are predominant (Figure 1c). Moreover, a large streamflow is located in the west of the basin with values that range between 41 and $94 \times 10^{6} \mathrm{~m}^{3}$. This streamflow is due to the large amount of precipitation (between 800 and $1137 \mathrm{~mm}$ ) that falls in this part of the basin.

In the historical view, most of the basin's surface consumed between 22 and $58 \times 10^{3} \mathrm{~m}^{3}$ of water. In the scenario of an increase in the irrigated area, the highest consumption ranged between 20 and $55 \times 10^{3} \mathrm{~m}^{3}$ of water. In the scenario of a projection to 2060 , the highest consumption ranged between 21 and $40 \times 10^{3} \mathrm{~m}^{3}$ of water (Figure 7). The highest consumption of water was registered in the Azibo river $\left(95 \times 10^{3} \mathrm{~m}^{3}\right.$ of water in the historical view, $87 \times 10^{3} \mathrm{~m}^{3}$ of water in the scenario of an increase in the irrigated area, and $66 \times 10^{3} \mathrm{~m}^{3}$ of water in the scenario of a projection to 2060). In the west of the basin, the highest irrigation deficits ranged between 4.8 and $7.8 \times 10^{6} \mathrm{~m}^{3}$ of water in the historical view, between 10.3 and $22 \times 10^{6} \mathrm{~m}^{3}$ of water in the scenario of an increase in the irrigated area, and between 12.7 and $24 \times 10^{6} \mathrm{~m}^{3}$ of water in the scenario of a projection to 2060 . In other words, the irrigation deficit increased in both scenarios when compared with the historical view.

Transverse barriers play an essential role in the storage of water for irrigation. The Sabor River basin has at least 129 transverse barriers, either dams or weirs [59] (Figure 10). Figure 10 shows that the transversal barriers are mainly located in the Sabor Superior river, the Angueira river, the Maças river, the Vilariça river, and downstream of the Baixo Sabor river (Figure 3). In these rivers, the streamflow ranges between 20 and $40 \times 10^{6} \mathrm{~m}^{3}$ and the main crops are olive groves, fruit trees, and horticulture (Figure 1c). These transversal barriers contribute to reducing the water deficit in these rivers. However, in rivers where the water deficit is higher (e.g., Vale of Moinhos, the Azibo river, and the Zacarias river), there is a lack of transversal barriers. 


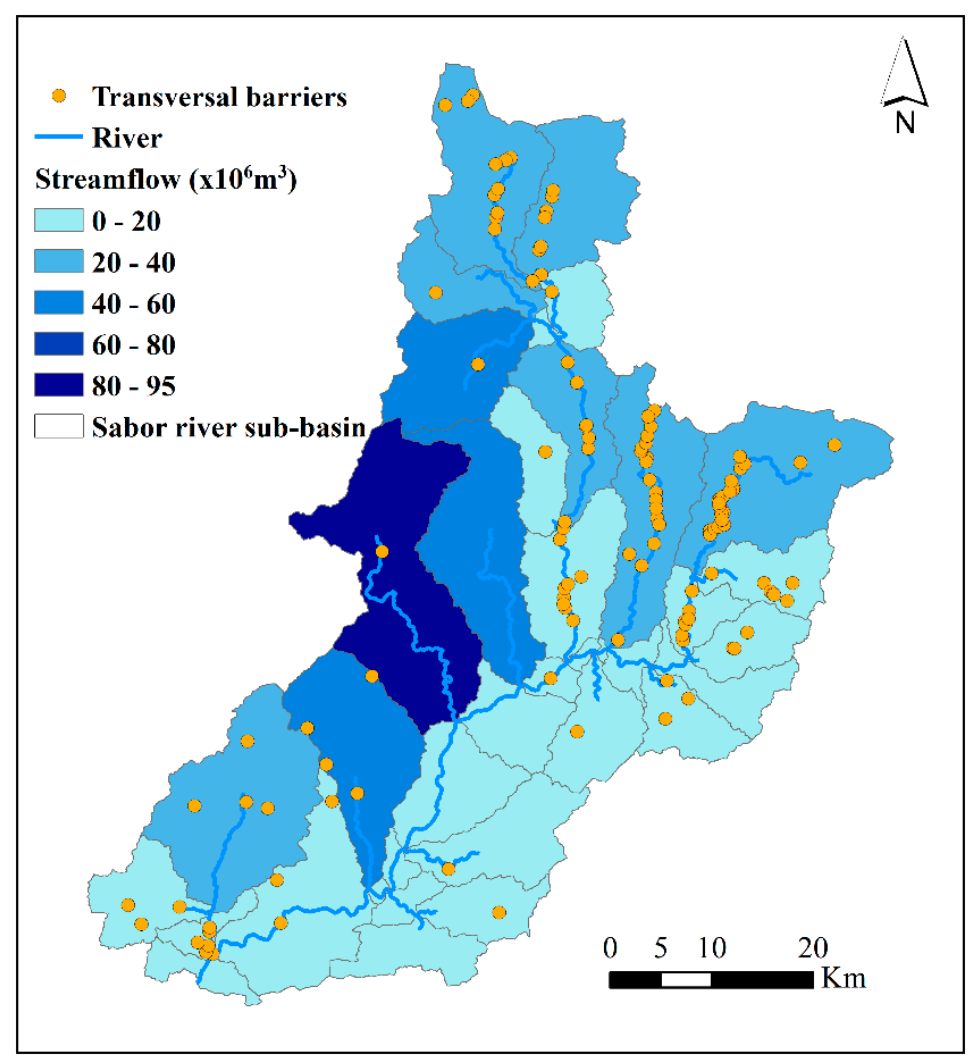

Figure 10. The spatial distribution of dams and weirs in the Sabor River basin and the annual average streamflow between 1960 and 2008.

\section{Conclusions}

This study evaluated the present and future agricultural sustainability of the Sabor River basin through the development of a hydrological and water allocation model (an integration of SWAT and MIKE HYDRO Basin). SWAT was used to model the components of the water balance, and MIKE HYDRO Basin was used to simulate the water allocation, irrigation, and domestic water consumption. The results show that the Sabor River basin does not have enough water to fulfil the requirements of the crops. In the historical view, between 1960 and 2008, $1372 \times 10^{3} \mathrm{~m}^{3}$ of water was found to be necessary for domestic water consumption and $94 \times 10^{6} \mathrm{~m}^{3}$ of water for irrigation. However, the average annual water demand deficit was $31 \%$ for domestic water consumption and $70 \%$ for irrigation. Therefore, to fulfil the crop requirements, $422 \times 10^{3} \mathrm{~m}^{3}$ more water is necessary for domestic consumption and $65.4 \times 10^{6} \mathrm{~m}^{3}$ more water is necessary for irrigation. The high water demand deficit, especially for irrigation, is due to the variation in river flow that exists during the year and the low flow period in spring and summer, which is exactly when irrigation demand is higher.

In the scenario of an increase in the irrigated area from 181.6 to $586.8 \mathrm{~km}^{2}$, the water demand deficit of domestic consumption increased to $37 \%$, and the water demand deficit of irrigation increased to $77 \%$. Therefore, to fulfil the crop requirement, $506 \times 10^{3} \mathrm{~m}^{3}$ more water is necessary for domestic consumption and $183 \times 10^{6} \mathrm{~m}^{3}$ more water is necessary for irrigation. The same percentage of water demand deficit was obtained in the scenario of a projection to 2060. In 2060, a $24 \%$ decrease in the resident population is expected, which will represent five less inhabitants. $\mathrm{km}^{2}$, along with a $29 \%$ increase in the irrigation area of olive groves, which will represent an additional $172 \mathrm{~km}^{2}$ of area. In this scenario, we found the demand deficit to be $385 \times 10^{3} \mathrm{~m}^{3}$ of water for domestic consumption, and $106 \times 10^{6} \mathrm{~m}^{3}$ of water for irrigating the olive grove area. Overall, this work provides a reference to stakeholders and decision-makers on how much water is being consumed in the Sabor River basin and how much water needs to be stored to fulfil the present and future water demand. 
Supplementary Materials: The following are available online at http://www.mdpi.com/1660-4601/16/13/2419/s1. The supplementary materials comprise the following worksheets: Worksheet 1 -The crops attributed to each class of COS2007 (level five) and the respective areas; Worksheet 2-calculations for the reference irrigation allocation; Worksheet 3-values of irrigated area per sub-basin; Worksheet 4-area of each irrigable crop per sub-basin; Worksheet 5-olive grove area's expansion per sub-basin.

Author Contributions: conceptualization, R.M.B.S. and F.A.L.P.; methodology, R.M.B.S. and F.A.L.P.; software, R.M.B.S.; validation, F.A.L.P.; formal analysis, L.F.S.F.; investigation, R.M.B.S.; resources, L.F.S.F. and R.M.V.C.; data curation, R.M.B.S., F.A.L.P., L.F.S.F. and R.M.V.C.; writing-original draft preparation, R.M.B.S.; writing-review and editing, F.A.L.P.; visualization, R.M.B.S.; supervision, F.A.L.P. and L.F.S.F.; project administration, R.M.V.C.; funding acquisition, R.M.V.C.

Funding: This research was funded by the INTERACT project "Integrated Research in Environment, Agro-Chain and Technology", no. NORTE-01-0145-FEDER-000017, in the line of research entitled BEST "Bio-economy and Sustainability", and co-financed by the European Regional Development Fund (ERDF) through NORTE 2020 (the North Regional Operational Program 2014/2020). For authors at the CITAB research centre, this research was further financed by the FEDER/COMPETE/POCI-Operational Competitiveness and Internationalization Programme under Project POCI-01-0145-FEDER-006958, and by National Funds of FCT-Portuguese Foundation for Science and Technology under the project UID/AGR/04033/2019. For the author in the CQVR, this research was additionally supported by National Funds of FCT-Portuguese Foundation for Science and Technology under the project UID/QUI/00616/2019.

Conflicts of Interest: The authors declare no conflict of interest. The funders had no role in the design of the study; in the collection, analyses, or interpretation of data; in the writing of the manuscript or in the decision to publish the results.

\section{References}

1. GMAFDR - Gabinete do Ministro da Agricultura das Florestas e do Desenvolvimento Rural. Governo Apresenta Programa Nacional de Regadios. Available online: https:/www.portugal.gov.pt/downloadficheiros/ficheiro.aspx?v=33d58ebb-767c-48e9-953c-c6318fc1c69a (accessed on 29 March 2019).

2. APA—Agência Portuguesa do Ambiente. Plano de Gestão da Região Hidrográfica do Douro—RH3 Relatório de Base, Parte 2-Caracterização e Diagnóstico da Região Hidrográfica; Agência Portuguesa do Ambiente: Lisbon, Portugal, 2016; pp. 1-213.

3. INE-Instituto Nacional de Estatística. Recenseamento Agrícola 2009: Dados definitivos. In Destaque —Informação à Comunicação Social; Instituto Nacional de Estatística: Lisbon, Portugal, 2011; pp. 1-13.

4. INE-Instituto Nacional de Estatística. Recenseamento Agrícola 2009-Análise dos Principais Resultados; Instituto Nacional de Estatística: Lisbon, Portugal, 2011; pp. 1-62. ISBN 978-989-25-0108-6.

5. INE—Instituto Nacional de Estatística. Recenseamento Geral Agrícola 1989—Resultados Definitivos-Dados Gerais; Instituto Nacional de Estatística: Lisbon, Portugal, 1992; pp. 1-204. ISBN 972-673081-3.

6. INE-Instituto Nacional de Estatística. Recenseamento Geral da Agricultura 1999—Análise de Resultados; Instituto Nacional de Estatística: Lisbon, Portugal, 2001; pp. 1-128. ISBN 978-989-25-0108-6.

7. Kumar, A.; Singh, R.; Jena, P.P.; Chatterjee, C.; Mishra, A. Identification of the best multi-model combination for simulating river discharge. J. Hydrol. 2015, 525, 313-325. [CrossRef]

8. Rocha, J.; Roebeling, P.; Rial-Rivas, M.E. Assessing the impacts of sustainable agricultural practices for water quality improvements in the Vouga catchment (Portugal) using the SWAT model. Sci. Total Environ. 2015, 536, 48-58. [CrossRef] [PubMed]

9. DHI. MIKE HYDRO Basin User Guide 2017; DHI: Hørsholm, Denmark, 2017; pp. 1-216.

10. Doulgeris, C.; Georgiou, P.; Papadimos, D.; Papamichail, D. Water allocation under deficit irrigation using MIKE BASIN model for the mitigation of climate change. Irrig. Sci. 2015, 33, 469-482. [CrossRef]

11. SNIRH-Sistema Nacional de Informação de Recursos Hídricos. Available online: http://snirh.apambiente.pt/ (accessed on 29 November 2018).

12. Shakesby, R.A. Post-wildfire soil erosion in the Mediterranean: Review and future research directions. Earth-Sci. Rev. 2011, 105, 71-100. [CrossRef]

13. Nunes, A.N.; de Almeida, A.C.; Coelho, C.O.A. Impacts of land use and cover type on runoff and soil erosion in a marginal area of Portugal. Appl. Geogr. 2011, 31, 687-699. [CrossRef]

14. DGT Directorate-General of Territory. Available online: http://www.dgterritorio.pt/ (accessed on 28 November 2018). 
15. Agroconsultores-Engenharia de Recursos Agrários. Coba-Consultores de Engenharia e Ambiente Carta de solos, Carta do Uso Actual da Terra e Carta de Aptidão da Terra do Nordeste de Portugal; Universidade de Trás-os-Montes e Alto Douro: Vila Real, Portugal, 1991; pp. 1-311.

16. EEA-European Environmental Agency. Corine Land Cover. Available online: https://www.eea.europa.eu/ publications/COR0-landcover (accessed on 20 June 2018).

17. INE-Instituto Nacional de Estatística. O Uso da Água na Agricultura; Instituto Nacional de Estatística: Lisbon, Portugal, 2011; pp. 1-95. ISBN 978-989-25-0145-1.

18. INE-Instituto Nacional de Estatística. Estrutura da Origem da Água de Rega: Recenseamento Agrícola 2009; Direção-Geral de Agricultura e Desenvolvimento Rural: Lisbon, Portugal, 2011; p. 1.

19. INE Instituto Nacional de Estatística. Available online: https://www.ine.pt (accessed on 21 September 2018).

20. PORDATA—Data Base of Contemporary Portugal. Available online: https://www.pordata.pt/ (accessed on 20 September 2018).

21. COS. Carta de Uso e Ocupação do Solo de Portugal Continental para 2007 (COS 2007); Direção Geral do Território: Lisbon, Portugal, 2010; pp. 1-87.

22. EEA. Corine Land Cover technical guide: Addendum 2000; EEA-European Environmental Agency: Copenhagen, Denmark, 2000; pp. 1-105.

23. Neitsch, S.; Arnold, J.; Kiniry, J. Soil and Water Assessment Tool: Theoretical Documentation, Version 2009; Texas A\&M University System: College Station, TX, USA, 2011; pp. 1-647.

24. Arnold, J.G.; Moriasi, D.N.; Gassman, P.W.; Abbaspour, K.C.; White, M.J.; Srinivasan, R.; Santhi, C.; Harmel, R.D.; van Griensven, A.; Van Liew, M.W.; et al. SWAT: Model use, calibration, and validation. Trans. ASABE 2012, 55, 1491-1508. [CrossRef]

25. Pacheco, F.A.L.; Van der Weijden, C.H. Weathering of plagioclase across variable flow and solute transport regimes. J. Hydrol. 2012, 420-421, 46-58. [CrossRef]

26. Pacheco, F.A.L.; Szocs, T. “Dedolomitization reactions” driven by anthropogenic activity on loessy sediments, SW Hungary. Appl. Geochem. 2006, 21, 614-631. [CrossRef]

27. Pacheco, F.A.L. Application of Correspondence Analysis in the Assessment of Groundwater Chemistry. Math. Geol. 1998, 30, 129-161. [CrossRef]

28. Pacheco, F.A.L.; Landim, P.M.B. Two-Way Regionalized Classification of Multivariate Datasets and its Application to the Assessment of Hydrodynamic Dispersion. Math. Geol. 2005, 37, 393-417. [CrossRef]

29. Pacheco, F.A.L.; Sousa Oliveira, A.; Van Der Weijden, A.J.; Van Der Weijden, C.H. Weathering, biomass production and groundwater chemistry in an area of dominant anthropogenic influence, the Chaves-Vila Pouca de Aguiar region, north of Portugal. Water Air Soil Pollut. 1999, 115, 481-512. [CrossRef]

30. Pacheco, F.A.L. Finding the number of natural clusters in groundwater data sets using the concept of equivalence class. Comput. Geosci. 1998, 24, 7-15. [CrossRef]

31. Valera, C.A.; Pissarra, T.C.T.; Martins Filho, M.V.; Valle Junior, R.F.; Sanches Fernandes, L.F.; Pacheco, F.A.L. A legal framework with scientific basis for applying the 'polluter pays principle' to soil conservation in rural watersheds in Brazil. Land Use Policy 2017, 66, 61-71. [CrossRef]

32. Hughes, S.J.; Cabecinha, E.; Andrade dos Santos, J.C.; Mendes Andrade, C.M.; Mendes Lopes, D.M.; da Fonseca Trindade, H.M.; dos Santos Cabral, J.A.F.A.; dos Santos, M.G.S.; Lourenço, J.M.M.; Marques Aranha, J.T.; et al. A predictive modelling tool for assessing climate, land use and hydrological change on reservoir physicochemical and biological properties. Area 2012, 44, 432-442. [CrossRef]

33. Modesto Gonzalez Pereira, M.J.; Sanches Fernandes, L.F.; Barros Macário, E.M.; Gaspar, S.M.; Pinto, J.G. Climate Change Impacts in the Design of Drainage Systems: Case Study of Portugal. J. Irrig. Drain. Eng. 2015, 141, 05014009. [CrossRef]

34. Siqueira, H.E.; Pissarra, T.C.T.; do Valle Junior, R.F.; Fernandes, L.F.S.; Pacheco, F.A.L. A multi criteria analog model for assessing the vulnerability of rural catchments to road spills of hazardous substances. Environ. Impact Assess. Rev. 2017, 64, 26-36. [CrossRef]

35. SNIRH-National System of Water Resources Information. Available online: https://www.shirh.pt/ (accessed on 20 September 2018).

36. Santos, R.; Fernandes, L.; Cortes, R.; Pacheco, F. Hydrologic impacts of land use changes in the Sabor River Basin: A historical view and future perspectives. Water 2019. (submitted).

37. Abbaspour, K.C. SWATCUP Manual Calibration and Uncertainty Programs; Eawag-Swiss Federal Institute of Aquatic Science and Technology: Dübendorf, Switzerland, 2015; pp. 1-100. 
38. Moriasi, D.N.; Arnold, J.G.; Van Liew, M.W.; Bingner, R.L.; Harmel, R.D.; Veith, T.L. Model evaluation guidelines for systematic quantification of accuracy in watershed simulations. Trans. ASABE 2007, 50, 885-900. [CrossRef]

39. Valle Junior, R.F.; Varandas, S.G.P.; Sanches Fernandes, L.F.; Pacheco, F.A.L. Multi Criteria Analysis for the monitoring of aquifer vulnerability: A scientific tool in environmental policy. Environ. Sci. Policy 2015, 48, 250-264. [CrossRef]

40. Ferreira, A.R.L.; Sanches Fernandes, L.F.; Cortes, R.M.V.; Pacheco, F.A.L. Assessing anthropogenic impacts on riverine ecosystems using nested partial least squares regression. Sci. Total Environ. 2017, 583, 466-477. [CrossRef]

41. Sanches Fernandes, L.F.; Pacheco, F.A.L.; Cortes, R.M.V.; Jesus, J.J.B.; Varandas, S.G.P.; Santos, R.M.B. Integrative assessment of river damming impacts on aquatic fauna in a Portuguese reservoir. Sci. Total Environ. 2017, 601-602, 1108-1118.

42. Fonseca, A.R.; Sanches Fernandes, L.F.; Fontainhas-Fernandes, A.; Monteiro, S.M.; Pacheco, F.A.L. From catchment to fish: Impact of anthropogenic pressures on gill histopathology. Sci. Total Environ. 2016, 550, 972-986. [CrossRef] [PubMed]

43. Fonseca, A.R.; Sanches Fernandes, L.F.; Fontainhas-Fernandes, A.; Monteiro, S.M.; Pacheco, F.A.L. The impact of freshwater metal concentrations on the severity of histopathological changes in fish gills: A statistical perspective. Sci. Total Environ. 2017, 599-600, 217-226. [CrossRef] [PubMed]

44. Reshmi, T.V.; Christiansen, A.B.; Badiger, S.; Barton, D.N. Hydrology and Water Allocation in Malaprabha; Norwegian Institute for Water Research: Oslo, Norway, 2008; pp. 1-70. ISBN 9788257754303.

45. Santos, R.M.B.; Sanches Fernandes, L.F.; Moura, J.P.; Pereira, M.G.; Pacheco, F.A.L. The impact of climate change, human interference, scale and modeling uncertainties on the estimation of aquifer properties and river flow components. J. Hydrol. 2014, 519, 1297-1314. [CrossRef]

46. Yu, Y.; Disse, M.; Yu, R.; Yu, G.; Sun, L.; Huttner, P.; Rumbaur, C. Large-scale hydrological modeling and decision-making for agricultural water consumption and allocation in the main stem Tarim River, China. Water 2015, 7, 2821-2839. [CrossRef]

47. Fernandes, L.F.S.; Marques, M.J.; Oliveira, P.C.; Moura, J.P. Decision support systems in water resources in the demarcated region of Douro-case study in Pinhão river basin, Portugal. Water Environ. J. 2014, 28, 350-357. [CrossRef]

48. Pereira, M.G.; Fernandes, L.S.; Carvalho, S.; Santos, R.B.; Caramelo, L.; Alencoão, A. Modelling the impacts of wildfires on runoff at the river basin ecological scale in a changing Mediterranean environment. Environ. Earth Sci. 2016, 75, 1-14. [CrossRef]

49. Santos, R.M.B.; Sanches Fernandes, L.F.; Varandas, S.G.P.; Pereira, M.G.; Sousa, R.; Teixeira, A.; Lopes-Lima, M.; Cortes, R.M.V.; Pacheco, F.A.L. Impacts of climate change and land-use scenarios on Margaritifera margaritifera, an environmental indicator and endangered species. Sci. Total Environ. 2015, 511, 477-488. [CrossRef]

50. Álvarez, X.; Valero, E.; Santos, R.M.B.; Varandas, S.G.P.; Sanches Fernandes, L.F.; Pacheco, F.A.L. Anthropogenic nutrients and eutrophication in multiple land use watersheds: Best management practices and policies for the protection of water resources. Land Use Policy 2017, 69, 1-11. [CrossRef]

51. Sanches Fernandes, L.F.; Santos, C.M.M.; Pereira, A.P.; Moura, J.P. Climate change impacts on nitrogen in a hydrographical basin in the northeast of Portugal. Indian J. Med. Res. 2012, 25, 556-568.

52. Santos, R.M.B.; Sanches Fernandes, L.F.; Pereira, M.G.; Cortes, R.M.V.; Pacheco, F.A.L. A framework model for investigating the export of phosphorus to surface waters in forested watersheds: Implications to management. Sci. Total Environ. 2015, 536, 295-305. [CrossRef] [PubMed]

53. Sanches Fernandes, L.F.; Santos, C.M.M.; Perreira, A.P.; Moura, J.P. Model of management and decision support systems in the distribution of water for consumption. Eur. J. Environ. Civ. Eng. 2011, 15, 411-426. [CrossRef]

54. Allen, R.G.; Pereira, L.S.; Raes, D.; Martin, S. Crop Evapotranspiration-Guidelines for Computing Crop Water Requirements_FAO Irrigation and Drainage Paper 56; FAO_Food and Agriculture Organization of the United Nations: Rome, Italy, 1998.

55. INE-Instituto Nacional de Estatística. Dotações de Rega de Referência-Região Interior Norte e Centro; Direção-Geral de Agricultura e Desenvolvimento Rural: Lisbon, Portugal, 2017; pp. 1-3. 
56. INE-Instituto Nacional de Estatística. Projeção de População Residente 2012-2060; Instituto Nacional de Estatística: Lisbon, Portugal, 2014; pp. 1-18.

57. Caetano, M.; Igreja, C.; Marcelino, F. Especificações Técnicas da Carta de Uso e Ocupação do Solo de Portugal Continental Para 1995, 2007, 2010 e 2015; Direção-Geral do Território: Lisbon, Portugal, 2018; pp. 1-103.

58. Ronco, P.; Zennaro, F.; Torresan, S.; Critto, A.; Santini, M.; Trabucco, A.; Zollo, A.L.; Galluccio, G.; Marcomini, A. A risk assessment framework for irrigated agriculture under climate change. Adv. Water Resour. 2017, 110, 562-578. [CrossRef]

59. Cortes, R.; Peredo, A.; Terêncio, D.; Sanches Fernandes, L.; Moura, J.; Jesus, J.; Magalhães, M.; Ferreira, P.; Pacheco, F. Undamming the Douro River Catchment: A Stepwise Approach for Prioritizing Dam Removal. Water 2019, 11, 693. [CrossRef]

(C) 2019 by the authors. Licensee MDPI, Basel, Switzerland. This article is an open access article distributed under the terms and conditions of the Creative Commons Attribution (CC BY) license (http://creativecommons.org/licenses/by/4.0/). 